\title{
A CONSTRUÇÃo dE REQUISITOS PARA A PROLAÇÃO DA DECISÃo PARCIAL: ENTRE A COMPLEXIDADE DE QUESTÕES DE FATO E A CONCEPÇÃO DE INDEPENDÊNCIA FÁTICA ${ }^{1}$
}

\author{
THE CONSTRUCTION REQUIREMENTS FOR THE PRONUNCIATION OF \\ PARTIAL DECISION: BETWEEN THE COMPLEXITY OF ISSUES OF FACT \\ ISSUES AND THE CONCEPTION OF PHATIC INDEPENDENCE
}

Vinícius da Silva Lemos

Doutor em Direito Processual pela UNICAP. Mestre em Sociologia e Direito pela UFF. Especialista em Processo Civil pela FARO. Professor de Processo Civil na FARO e UNIRON. Presidente do Instituto de Direito Processual de Rondônia - IDPR. Membro da Associação Norte-Nordeste de Professores de Processo - ANNEP. Membro do Centro de Estudos Avançados em Processo CEAPRO. Membro da Academia Brasileira de Direito Processual Civil - ABDPC. Membro da Associação Brasileira de Direito Processual - ABDPRO. Membro da Instituto Brasileiro de Direito Processual - IBDP. Advogado. Porto Velho/RO. Email: viniciuslemos.ro@gmail.com.

\begin{abstract}
RESUMO: Este artigo aborda o estudo da complexidade objetiva do processo e a sua relação com a viabilidade da prolação de uma decisão parcial. A cisão cognitiva e processual do processo necessita de requisitos gerais para a sua construção e, diante desses, as questões de fato são pertinentes e essenciais, com a necessidade de analisar a própria complexidade destas questões e a sua relação com a decisão parcial, formando um conglomerado de requisitos, diante dos diálogos específicos com cada capítulo da jurisdição. O intuito é entender o impacto das questões de fato na construção dos requisitos para a prolação da decisão parcial, com ou sem resolução do mérito.
\end{abstract}

\footnotetext{
${ }^{1}$ Artigo recebido em 22/05/2021 e aprovado em 04/06/2021.
} 
PAlaVRAS-CHAVE: Decisão Parcial; Cisão Cognitiva; Processo Objetivamente Complexo; Questões de Fato.

\begin{abstract}
This article discusses the study of the objective complexity of the process and its relationship with the feasibility of pronunciation a partial decision. The cognitive and procedural division of the process requires general requirements for its construction and, before these, the issues of fact are relevant and essential, with the need to analyze the very complexity of these issues and their relationship with the partial decision, forming a conglomerate of requirements, before the specific dialogues with each chapter of the jurisdiction. The aim is to understand the impact of the issues of fact in the construction of the requirements for the pronunciation of the partial decision, with or without resolution of the merits.
\end{abstract}

KEYWORDS: Partial decision; Cognitive Division; Objectively Complex Process; Issues of Facts.

\title{
INTRODUÇÃO
}

A jurisdição nasce a partir da iniciativa de um indivíduo em pleitear ao Estado a solução de um conflito e a concessão de um direito. Diante disso, nasce a necessidade da heterocomposição, da resposta jurisdicional ao pleito realizado.

O pedido de jurisdição detém uma divisão entre capítulos decisórios, ao menos da procedimentalidade entre uma análise processual, com a relação sobre o cumprimento dos pressupostos processuais, e uma análise de mérito, com relação ao pedido realizado pelo autor daquela ação.

No entanto, a jurisdição pode ser plural, com a possibilidade, além da divisão básica de capítulos entre admissibilidade e mérito, de conter diversas relações jurídicas a serem resolvidas, dada a abertura para pluralidade de partes ou uma cumulação de pedidos realizados.

A prestação jurisdicional complexa em seu objeto do processo ocorre igualmente na sentença, quando o juízo responde todos os pedidos realizados no processo, se a demanda for admissível, contudo diante da positivação dos arts. 354, parágrafo único e 356 do CPC 
é possível a decisão parcial, com o julgamento de parcela da jurisdição e a postergação do restante para a prolação de uma sentença que finda aquela fase do processo.

Logo, o CPC/2015 trabalha com a unicidade da sentença, mas permite uma decisão parcial, seja com resolução de mérito, seja sem resolução de mérito.

Para que seja possível uma cindibilidade da jurisdição, com a decisão de um capítulo - decisão parcial - e que a continuidade de outro, vários requisitos devem ser cumpridos e estarem presentes naquele processo.

De plano, facilmente se entende que há a necessidade de uma complexidade do objeto do processo, seja por cumulação de pedidos, seja pela pluralidade de partes em um dos polos do processo, porém o presente trabalho tem como objeto de estudo a relação da decisão parcial com os seus requisitos autorizantes, focando na análise das questões de fato e a sua necessária complexidade na demanda para que seja possível a cisão cognitiva e procedimental, culminando na decisão parcial.

Dessa maneira, o recorte do presente estudo é essa relação entre a decisão parcial e a necessidade de uma complexidade de questões de fato como um dos requisitos dessa cisão cognitiva, com uma análise profunda sobre essas questões, suas espécies e impactos na demanda e diálogo com a própria complexidade objetiva do processo.

Diante disso, o estudo descreve, além da base teórica e conceitual da complexidade do processo, a complexidade da cognição, a relação com as questões de fato e o qual a importância destas questões serem resolúveis para o diálogo e autorização com a decisão parcial. Para tanto, utiliza da pesquisa bibliográfica sobre o assunto, diante do método dedutivo.

\section{A COMPLEXIDADE DO PROCESSO E DA COGNIÇÃO}

A jurisdição é exercida a partir de um pleito de um indivíduo que tem em sua concepção a legitimidade diante de uma pretensão a obter uma tutela para uma situação em concreto ainda passível de resolução. A jurisdição é exercida pelo Estado ${ }^{2}$ como uma

2 Em regra pelo Estado, mas com possibilidades abertas para a arbitragem, por exemplo. 
Rio de Janeiro. Ano 15. Volume 22. Número 3. Setembro a Dezembro de 2021

Periódico Quadrimestral da Pós-Graduação Stricto Sensu em Direito Processual da UERJ

Patrono: José Carlos Barbosa Moreira (in mem.). ISSN 1982-7636. pp. 1067-1124

www.redp.uerj.br

heterocomposição, ou seja, pela substituição ${ }^{3}$ da relação entre as partes e sua possível autotutela ou autocomposição pela função estatal e o seu resultado judicante.

Essa tutela jurídica pode ser para a solução de um conflito entre indivíduos ou somente de maneira voluntária.

A jurídica contenciosa é aquela que o demandante não tem solução administrativa ou consensual, postulando ao Judiciário uma solução por heterocomposição, apresentando para tanto, sua narrativa e sua proposta de resolução daquele conflito, daquele litígio.

Uma vez diante da existência desse problema judicializado por um dos indivíduos, dada a ciência do conflito de interesse entre as partes, o Estado, a partir desta provocação, detém o poder de solucioná-lo, prestando a jurisdição aplicando o melhor direito possível para aquela situação em concreto.

Por outro lado, em determinadas situações concretas, há a necessidade de jurisdição ainda que não haja propriamente dito um conflito, inserindo nestes exemplos a ações de jurisdição voluntária ${ }^{4}$, quando não há réu para que haja um contencioso, bem como as ações declaratórias, que somente detém a serventia de declarar um direito já preexistente, ainda que contenciosa. Ambos também são maneiras de exercício da jurisdição pelo Estado, com ou sem conflito.

Dessa maneira, conceitualmente, jurisdição é o poder estatal de exercer a heterocomposição para a solução de conflitos ou para resolver uma situação jurídica que a atuação do Estado é necessária, independentemente de conflito e, em ambos, o meio de aplicação da norma jurídica para aquela situação concreta posta em juízo.

3 “A ideia de transferência e substituição está atrelada a condição de que esse órgão a quem cabe a decisão deve, aplicando o direito, proferir uma decisão que restabelecendo o fato ocorrido seja capaz de determinar as consequências jurídicas dele decorrentes na medida em que pretendidas pelas partes em conflito." DIAS, Jean Carlos. Reflexões acerca da teoria da cognição no processo. Argumenta (FUNDINOPI), v. 6, p. 203-219, 2006. p. 204.

4 A jurisdição voluntária é evidentemente diversa daquela contenciosa, pelo fato de que não há um conflito de interesses, mas há a necessidade de intervenção estatal, para exercício daquele direito. Dessa maneira, o comum é ampliar-se a concepção e conceituação de jurisdição para englobar todos esses termos, sem ser de modo estanque. Silva já delineava que não existia o conflito: "Denomina-se jurisdição voluntária a um complexo de atividades confiadas ao Juiz nas quais, ao contrário do que acontece com a jurisdição contenciosa, não há litígio entre os interessados (...) “A atividade de jurisdição voluntária é apenas mediadora e, nesse sentido, instrumental entre o interesse tutelado e seu respectivo titular, tendo por função exclusiva a remoção de um obstáculo - criado pela lei - a fim de que o interessado tenha satisfeito e realizado o interesse tutelado pela ordem jurídica." SILVA, Ovídio Araújo Baptista da. Teoria geral do processo civil. São Paulo: Ed. RT, 1997. p. 81. 
A jurisdição é o meio em que o Poder Judiciário, como representante estatal, responde e soluciona as situações concretas que lhe são apresentadas, independentemente do caso em concreto que lhe seja posto, com os limites que as próprias partes inserem na demanda.

\subsection{A possibilidade de complexidade objetiva do processo no exercício da jurisdição}

Diante do pleito e o exercício da jurisdição, uma demanda, quanto ao seu objeto, pode ser simples ou complexa.

A simples será uma só pretensão deduzida que tem como partes um autor e um réu. O transcorrer do procedimento está envolto sempre a uma unidade, a decorrer, a priori, uma processualística mais simples.

Ao contrário, a demanda objetivamente complexa é aquela ação que contém pluralidade de pedidos ou de partes, com uma série de pretensões a serem expostas ao mesmo tempo, impondo uma necessidade ao juízo responder todos os pleitos ali existentes para o exercício da jurisdição, tornando o objeto do processo uma complexidade de relações jurídicas a serem resolvidas.

Em sua base, o processo civil é voltado, em sua maioria construtiva, a organizar, primordialmente, o processo de maneira simples em seu objeto, a construir uma evolução gradual para o entendimento da simplicidade e, somente após, com alguns dispositivos autorizantes de menção à complexidade e a pluralidade de resoluções jurídicas em mesmo processo, como o litisconsórcio, intervenção de terceiros ou cumulação de pedidos.

Primeiro entende-se o processo como uma relação entre duas partes - autor e réu e um pedido, constituindo uma relação jurídica a ser respondida e solucionada, depois o ordenamento possibilita uma série de intersecções que este processo se adapte à complexidade de relações jurídicas, como diversas partes ou diversos pedidos.

Nessa conjuntura, é complexo objetivamente o processo que enseja a prolação de uma sentença que contenha mais de uma decisão interna em seu mérito ${ }^{5}$. Obviamente que a

\footnotetext{
Barbosa Moreira foca a sua conceituação de processo complexo objetivamente a partir do prisma da sentença ser complexa: "Numa primeira aproximação, poderiam assim definir-se as sentenças cujo dispositivo contém mais de uma decisão. Também seria possível caracterizar a sentença objetivamente complexa aquela que se compõe de mais de um capítulo.” BARBOSA MOREIRA, José Carlos. Sentença objetivamente complexa, trânsito em julgado e rescindibilidade. Revista Dialética de Direito
} 
Rio de Janeiro. Ano 15. Volume 22. Número 3. Setembro a Dezembro de 2021

Periódico Quadrimestral da Pós-Graduação Stricto Sensu em Direito Processual da UERJ

Patrono: José Carlos Barbosa Moreira (in mem.). ISSN 1982-7636. pp. 1067-1124

www.redp.uerj.br

cumulação de pedidos enseja essa pluralidade de decisões no ato decisório, tornando-se complexo, no entanto, há a possibilidade de um só pedido também tornar a sentença objetivamente complexa quando houver a possibilidade de decomposição do pedido.

A complexidade objetiva do processo inicia-se na cumulação do próprio ato de demandar, seja pela pluralidade de pedidos, seja na pluralidade de partes.

Uma vez que o autor cumula pedidos em sua petição inicial, não será somente uma pretensão deduzida em juízo, ao inverso, serão quantas forem pleiteadas, cada qual com a exigência de resposta sobre o acolhimento ou não, bem como sobre a sua admissibilidade específica. Essa cumulação de pedidos pode ser em momento ulterior, pelo réu, por exemplo, também tornando o processo complexo em seu objeto em eventual reconvenção ou pedido contraposto.

A pluralidade de partes - fora o litisconsórcio unitário ${ }^{6}$ - enseja também uma pluralidade de relações jurídicas em juízo, com cada qual representando um objeto diverso e, por isso, necessário ser considerado complexo para a construção dos argumentos das partes, produção de provas, atos processuais até a sentença e sua recorribilidade.

\subsection{Uma outra complexidade: a cognição complexa através de pluralidade de questões}

Partindo de uma situação em que há um processo complexo, com uma pluralidade de partes ou de pedidos, naturalmente é de se prever que, igualmente, haverá uma complexidade nas questões cognitivas, culminando numa pluralidade de questões a serem conhecidas, enfrentadas e resolvidas.

A pluralidade de questões já é inerente à própria processualidade, uma vez que numa ação existirão questões preliminares, prejudiciais e de mérito, além de questões de fato e de direito, as quais não são conceitos isolados, com uma questão podendo ser de fato

Processual. Vol. 45, São Paulo: Dialética, dez/2006. p. 54. Já Dinamarco expõe a mesma complexidade através do objeto do processo, mas com resultado idêntico a Barbosa Moreira: "A complexidade do objeto do processo, seja em virtude da cumulação de pedidos na demanda de vida pelo autor, seja pela superveniência de pedidos (reconvenção, etc,), repercute necessariamente na sentença de mérito mediante a necessária a presença de tantos capítulos quantos forem os pedidos postos dia do juiz à espera do julgamento." DINAMARCO, Cândido Rangel. Capítulos de sentença. 3a. ed. São Paulo: Malheiros, 2008. p. 42.

6 "um só pedido e uma só decisão, embora endereçada simultaneamente a dois, a três ou a vários." DINAMARCO, Cândido Rangel. Capítulos de sentença. 3a . ed. São Paulo: Malheiros, 2008. p. 74. 
e preliminar ou de direito e preliminar, de direito e prejudicial e, seguindo nessa interligação e complexidade.

Logo, todo processo já traz uma série de questões a serem resolvidas pela cognição judicial $^{7}$, independente da quantidade de partes, pluralidade ou não de pedidos e sua complexidade objetiva. Todavia, quando se imaginar que um processo terá uma complexidade objetiva, seja pela pluralidade de partes, seja pela cumulação de pedidos, evidentemente que refletirá, igualmente, numa multiplicidade de questões a serem resolvidas, via cognição judicial.

Se há uma cumulação de pedidos, há uma conjunção de diversas ações no mesmo processo, com a necessidade de que o juízo decida, prestando devidamente jurisdição, sobre cada um desses pedidos e, consequentemente, com a igual pertinência de que enfrente as questões inerentes a cada um desses pedidos, o que torna ainda mais complexa a atividade judicante ${ }^{8}$, com um emaranhado de questões a serem conhecidas, enfrentadas e resolvidas, com uma clara complexidade cognitiva.

Se a pluralidade for de partes, haverá uma pluralidade de relações jurídicas, com uma relação específica entre cada parte com o outro polo ${ }^{9}$, ensejando ao mesmo tempo

7 Assis relaciona o objeto do processo, com o objeto da cognição, com a necessidade de que sejam resolvidas várias questões, uma vez que o objeto litigioso do processo se difere do primeiro instituto: "Objeto da cognição do juiz, que abrange o próprio processo, adquire uma dimensão maior que o objeto litigioso, ou thema decidendum, ou mérito, em princípio definido, irreversivelmente, como a ação material.” ASSIS, Araken de. Cumulação de ações. 4a. ed. São Paulo: Ed. RT, 2002. p. 120.

8 "O processo cumulativo necessita de disciplina própria, conforme a respectiva espécie, e apresenta inúmeras dificuldades no que tange à técnica do julgamento do mérito, a distribuição das despesas do processo, e o efeito devolutivo da apelação. Por exemplo, formulando o autor dois pedidos, um em caráter principal, o outro subsidiário, ensejando que o juiz somente examine este na hipótese de rejeição daquele, na chamada cumulação eventual (omissis), a teor do art. 326, caput, do NCPC, surgirá ao menos dois problemas no caso de o juiz efetivamente rejeitar o pedido antecedente e acolher o pedido subsequente, a saber: (a) a existência de decaimento parcial do autor, com o fito de atribuir-lhe, em parte, os ônus da sucumbência; (b) a possibilidade de o autor recorrer, postulando o acolhimento do pedido principal, e, faltando essa iniciativa, a do órgão ad quem apreciar o pedido rejeitado, no caso de prover a apelação do réu quanto ao pedido secundário. Por outro lado, acolhido o pedido principal, há outra questão: a possibilidade de o órgão $a d$ quem, provendo a apelação do réu quanto a esse pedido, estimar devolvido o conhecimento do segundo pedido, e passar a julgá-lo diretamente, havendo sido produzidas provas suficientes para tal juízo." ASSIS, Araken de. Processo civil brasileiro: parte geral fundamentos e distribuição de conflitos. Vol. I, São Paulo: Ed. RT, 2015. p. 537.

9 Quando o litisconsórcio for não unitário, a pluralidade de partes cria uma pluralidade de relações jurídicas, de demandas internas no processo, sendo uma cumulação, de certo modo, de pedidos, apesar de ser de partes diferentes, a cada relação entre cada autor e cada réu. "Em casos assim o que se tem é uma pluralidade jurídica de demandas, também unidas só formalmente; cada um dos litisconsortes é parte legítima apenas com referência àquela porção do objeto do processo que lhe diz respeito, e, consequentemente, entende-se que seu petitum se reduz a essa parcela. Trata-se, efetivamente, de um cúmulo de demandas, não só subjetivo mas também objetivo, na medida em que à pluralidade de sujeitos 
Rio de Janeiro. Ano 15. Volume 22. Número 3. Setembro a Dezembro de 2021

Periódico Quadrimestral da Pós-Graduação Stricto Sensu em Direito Processual da UERJ

Patrono: José Carlos Barbosa Moreira (in mem.). ISSN 1982-7636. pp. 1067-1124

www.redp.uerj.br

uma complexidade subjetiva e objetivo ao processo. Fora a hipótese de um litisconsórcio unitário $^{10}$, nas demais possibilidades, se tiver mais de um autor ou réu, cada um destes, individualmente, se relaciona com cada parte do outro polo, tendo uma relação jurídica específica, com pedidos específicos e, assim, com questões cognitivas inerentes a cada uma dessas relações, multiplicando o que deve ser conhecido, enfrentado e resolvido pelo juízo, em cada relação jurídica.

Desse modo, uma complexidade objetiva do processo proporciona uma complexidade de questões ainda maior do que uma eventual existência de algumas questões numa ação que seja relacionalmente simples, com uma parte em cada polo e somente um pedido.

Essa complexidade de questões não funciona de modo estanque, com relações isoladas a cada relação e a cada pedido, é natural que algumas questões sejam ao mesmo tempo influenciantes em um ou mais pedido, em uma ou em várias relações. Uma vez que se resolva uma destas possíveis questões, pode-se resolver diversas relações ou influenciálas, o que permite diversos outros desdobramentos, dependendo da resolução das questões e o caminho decisório a ser trilhado.

\section{A POSSIBILIDADE DE CISÃO COGNITIVA COMO CONSEQUÊNCIA DA COMPLEXIDADE DO PROCESSO}

A complexidade objetiva do processo proporciona uma multiplicidade de questões e uma divisão entre pedidos e ações dentro de um mesmo processo. Se terão diversas ações e pedidos num mesmo processo, ou diversas partes, igualmente terão relações jurídicas múltiplas, com divisão em capítulos diferentes da mesma ação ${ }^{11}$, com necessários

corresponde uma soma de pedidos, todos eles amalgamados no complexo objeto que esse processo tem." DINAMARCO, Cândido Rangel. Litisconsórcio. 8a . ed. São Paulo: Malheiros, 2009. p. 86.

10 Não se pode cindir a cognição pela pluralidade de partes se o litisconsórcio for unitário. Lucca menciona, no entanto, a possibilidade da cisão cognitiva se todos os litisconsortes forem atingidos por igual, porém essa menção é quase que irrelevante, pelo fato de que a cisão cognitiva seria pela cumulação de pedidos e não pela pluralidade de partes. "Se o cúmulo for subjetivo, não poderá ser proferida decisão de mérito parcial para apenas um dos litisconsortes unitários (art. 116 do NCPC). Trata-se de vedação ínsita à própria categoria jurídica. A fragmentação do mérito somente será autorizada se o julgamento parcial abranger todos os litisconsortes unitários." LUCCA, Rodrigo Ramina de. Julgamentos antecipados parciais de mérito. Revista de Processo. Vol. 257, Ano 41, p. 125-150. São Paulo: RT, jul/2016. p. 139.

11 Sobre os capítulos de sentença, por Dinamarco: "Foi aí que se chegou à noção anunciada no item precedente, onde se define os capítulos de sentença como unidades autônomas do decisório da sentença - 
Rio de Janeiro. Ano 15. Volume 22. Número 3. Setembro a Dezembro de 2021

Periódico Quadrimestral da Pós-Graduação Stricto Sensu em Direito Processual da UERJ

Patrono: José Carlos Barbosa Moreira (in mem.). ISSN 1982-7636. pp. 1067-1124

www.redp.uerj.br

enfrentamentos e decisões para cada ponto, e, assim, igualmente terão, também, uma multiplicidade de questões a serem resolvidas.

Toda essa complexidade objetiva do processo proporciona uma multiplicidade de questões para a cognição judicial, sendo esta naturalmente dividida em diversas questões, com a necessidade de que o juízo enfrente, por exemplo, cada ponto sobre pressupostos processuais, sobre o cumprimento ou não destes, bem como eventuais questões preliminares ou prejudiciais, com o enfrentamento dessa diversidade de questões para alcançar a possibilidade de estar apto a resolver a própria demanda, da cognição sobre as questões de direito e poder julgar o objeto litigioso do processo - ou objetos litigiosos do processo por causa da complexidade objetiva deste.

Desse modo, para a decisão final e pretendida pelo autor em qualquer processo, o juízo deve ultrapassar uma série de cognições, diante do devido andamento procedimental, com a análise de preliminares e prejudiciais ${ }^{12}$, resolução de questões de fato e de direito, culminando na possibilidade de julgar a demanda, julgar cada pedido, analisando todas as questões de mérito, respondendo a cada um dos pleitos do autor, pela procedência ou improcedência de cada pedido ou de cada relação jurídica, o que perfaz uma notória complexidade objetiva de questões cognitivas no processo, independentemente da complexidade objetiva do processo, mas esta aumenta a pluralidade de questões cognitivas a serem enfrentadas.

Se qualquer ato postulatório já detém uma pluralidade de cognição, com no mínimo uma bipartição entre questões de admissibilidade e mérito ${ }^{13}$, quando há uma complexidade objetiva do processo, com uma profusão de questões que devem ser resolvidas, seja na

o que importa, de um lado, incluir todas as unidades elementares portadoras de concreto preceitos imperativos sobre a causa e sobre o processo e, de outro, excluir soluções dadas, na motivação sentencial, as questões de fato e de direito." DINAMARCO, Cândido Rangel. Capítulos de sentença. $3^{\text {a }}$. ed. São Paulo: Malheiros, 2008. p. 37.

12 Sobre preliminares e prejudiciais: "No curso de uma causa, muitas vezes o juiz quer examinar vários pontos, que são premissas para a decisão final sobre o pedido do autor. Esses pontos são preliminares, ou prejudiciais, à questão principal, quando surge entre as partes controvérsias sobre esses pontos, transformam-se eles em questões preliminares, ou questões prejudiciais”. BARBI, Celso Agrícola. Ação declaratória principal e incidental. 7a. ed. Rio de Janeiro: Forense, 1995. p. 166. No mesmo sentido: BARBOSA MOREIRA, José Carlos. Questões prejudiciais e questões preliminares. Direito processual civil (ensaios e pareceres). Rio de Janeiro: Borsoi, 1971. p. 76.

13 "tanto pode haver capítulos distintos, alusivos apenas ao processo (sem julgar o mérito), como ainda a convivência entre uns e outros, ou seja, entre capítulos de meritis e processuais." DINAMARCO, Cândido Rangel. Capítulos de sentença. $3^{a}$. ed. São Paulo: Malheiros, 2008. p. 40. 
Rio de Janeiro. Ano 15. Volume 22. Número 3. Setembro a Dezembro de 2021

Periódico Quadrimestral da Pós-Graduação Stricto Sensu em Direito Processual da UERJ

Patrono: José Carlos Barbosa Moreira (in mem.). ISSN 1982-7636. pp. 1067-1124

www.redp.uerj.br

admissibilidade, seja como preliminar, seja em prejudicial, seja questão de fato, seja no próprio mérito, tornando muito mais complexo o próprio exercício da cognição.

Se num processo de relação simples - um pedido e uma parte em cada polo - já existe, no mínimo, uma dualidade de cognições, dada a existência de uma admissibilidade e mérito, quando há uma complexidade objetiva do processo, além da visualização normal de diversas cognições, é possível que estas sejam cindidas, com a viabilidade de um fracionamento decisório, pelo fato de que terão pontos de análise diversos que não guardam dependência ${ }^{14}$ entre si, podendo um ser julgado e outro ainda depender da resolução de questões inerentes à sua própria resolução.

Essa é a abertura para uma cisão cognitiva do processo, com a possibilidade de prolação de uma decisão específica sobre parcela do processo, cumprindo essa parcela de jurisdição e o prosseguimento do restante com a jurisdição ainda a ser prestada.

Portanto, se parcela do processo objetivamente complexo puder ser resolvida desde logo, não haverá óbice para tanto ${ }^{15}$, diferentemente de um processo simples, quando a separação da cognição entre admissibilidade e mérito é normal e existente, contudo se o juízo decidir pela extinção, esta será sobre a totalidade do processo e, se ultrapassar essa fase, passará para a cognição a caminho de julgar o mérito também sobre a totalidade, uma vez que somente há um pedido - e uma relação jurídica - sem pluralidade de partes.

No processo com complexidade objetiva o panorama é outro ${ }^{16}$, como são diversas relações jurídicas com pedidos cumulados ou pluralidade de partes, cada uma destas detém

14 "Essa dependência pode ser vista em todos os casos nos quais se apresente uma relação de prejudicialidade entre duas pretensões, de modo que o julgamento de uma delas (prejudicial) determinará o teor julgamento da outra (prejudicada)." DINAMARCO, Cândido Rangel. Capítulos de sentença. $3^{\mathrm{a}}$. ed. São Paulo: Malheiros, 2008. p. 43.

15 "não faria sentido que as demandas fossem cumuladas por medida de economia, para que, a partir de então, jamais pudessem ser separadas, mesmo que isso importasse em amarrar o andamento de uma por conta das demais." SICA, Heitor Vitor Mendonça. Algumas implicações do novo conceito de sentença no processo civil, de acordo com a lei $\mathrm{n}^{\circ}$. 11.232/2005. In: Carlos Alberto Carmona. (Org.). Reflexões sobre a reforma do Código de Processo Civil. $1^{a}$ ed. São Paulo: Atlas, 2007. p. 193.

16 Sobre a complexidade objetiva da demanda ser requisito da decisão parcial e o fracionamento decisório, via cisão cognitiva: “i) necessariamente, a existência de complexidade objetiva referente ao pedido, seja porque há cúmulo de pedidos, estando um ou alguns deles pronto para julgamento, seja porque, embora em um único pedido, há possibilidade de fracionamento. A redação do caput do art. 356, CPC, é, porém, atabalhoada. Isto porque, num primeiro momento, por força da expressão: "um ou mais dos pedidos formulados", aparentemente ela refere-se à hipótese de cumulação de pedidos; todavia, o termo: "ou parcela deles", contido na parte final dela, acaba por deixar dúvidas se se refere à possibilidade de algum (ou alguns) dos pedidos cumulados estar, parcialmente, pronto para julgamento ou se este é possível mesmo não havendo cumulação, pois o pedido formulado tem alguma de suas partes já em pé de resolução." GOUVEIA FILHO, Roberto P. Campos. O art. 356, CPC, é base normativa suficiente 
Rio de Janeiro. Ano 15. Volume 22. Número 3. Setembro a Dezembro de 2021

Periódico Quadrimestral da Pós-Graduação Stricto Sensu em Direito Processual da UERJ

Patrono: José Carlos Barbosa Moreira (in mem.). ISSN 1982-7636. pp. 1067-1124

www.redp.uerj.br

autonomia em relação a outra, com a abertura da possibilidade de cisão cognitiva $^{17} \mathrm{e}$ fracionamento decisório, uma vez que a multiplicidade de questões cognitivas acompanha cada parcela da demanda, não o todo.

Ou seja, a admissibilidade passa ser sobre cada parcela do processo, não sobre o todo de modo estanque e inflexível e, posteriormente, quando ultrapassar a admissibilidade, cada mérito existente é diverso entre si, com autonomia ${ }^{18}$ e, a priori, independência.

Se um dos pedidos cumulados não ultrapassar a admissibilidade, nada impede que outro pedido prossiga, caso neste os pressupostos de admissibilidade estejam presentes especificadamente. Cada parte em litisconsórcio ou cada pedido terá a sua própria admissibilidade, de maneira apartada ao restante da demanda.

Em todo requerimento existente no processo há a necessidade de resposta judicial, contudo esta se dará em dois planos, uma no âmbito processual, com a verificação do cumprimento de pressupostos e requisitos e, outro, no âmbito material, após a análise de todos os argumentos e requerimentos, seja o pedido da demanda, seja qualquer requerimento interlocutório. A análise no segundo plano, sobre o que se requer, evidentemente, só ocorrerá se a análise do primeiro plano restar positiva, com plausibilidade processual para tanto ${ }^{19}$.

Logo, há primeiro a necessidade de cognição sobre sua admissibilidade ${ }^{20}$ para depois enfrentar-se o mérito, numa relação de clara interligação de antecedência e

para regular o fracionamento decisional? (final) https://emporiododireito.com.br/leitura/o-art-356cpc-e-base-normativa-suficiente-para-regular-o-fracionamento-decisional-final

17 "Se um direito (ou parcela de um direito) pode se mostrar controvertido, ou evidenciado, no curso do processo destinado a investigar a existência de outro direito (ou da outra parcela do direito) que requer instrução probatória, é necessário que este processo seja dotado de uma técnica que, atuando no seu interior, viabilize a realização imediata do direito incontrovertido. Isso porque é injusto obrigar o autor a esperar a realização de um direito que não se mostra controvertido." MARINONI, Luiz Guilherme. Tutela Antecipatória, julgamento antecipado e execução imediata da sentença. $2^{\mathrm{a}}$. ed. São Paulo: Ed. RT, 1998. p. 98 .

18 Autonomia tem diversas visões, mas não se confundem com independência. Pode ser um capítulo autônomo e dependente. DINAMARCO, Cândido Rangel. Capítulos de sentença. $3^{a}$. ed. São Paulo: Malheiros, 2008. p. 43.

19 “primeiro, verifica-se se será possível o exame do conteúdo da postulação; após, e em caso de um juízo positivo no primeiro momento, examina-se a procedência ou não daquilo que se postula". CUNHA, Leonardo Carneiro da; DIDIER JR., Fredie. Curso de direito processual civil. Vol. 3. 13a . ed. Salvador: JusPodivm, 2016. p. 105.

20 "Como todo ato postulatório, a impugnação de decisão judicial por meio de recurso submete-se a exame sob dois ângulos diversos. Primeiro, cumpre verificar se estão satisfeitas as condições impostas pela lei para que se possa apreciar o conteúdo da postulação (juízo de admissibilidade); depois, e desde que o 
Rio de Janeiro. Ano 15. Volume 22. Número 3. Setembro a Dezembro de 2021

Periódico Quadrimestral da Pós-Graduação Stricto Sensu em Direito Processual da UERJ

Patrono: José Carlos Barbosa Moreira (in mem.). ISSN 1982-7636. pp. 1067-1124

www.redp.uerj.br

subordinação. Não há análise de mérito sem uma anterior análise de admissibilidade, perfazendo, em qualquer requerimento e, assim, em qualquer processo, um mínimo de dualidade de análises.

Diante de tal complexidade mínima por causa da dualidade cognitiva existente em qualquer requerimento - admissibilidade e mérito, num processo objetivamente complexo essa mesma divisão é ainda mais complexa, culminando em microdivisões de admissibilidade e mérito sobre cada um dos diversos pontos do processo. A cada pedido realizado de jurisdição, há uma admissibilidade e igualmente um mérito, transformando a complexidade objetiva numa consequente complexidade cognitiva.

Dessa maneira, há, nos processos objetivamente complexos, uma repartição de cognições a cada pedido realizado. Cada um destes pedidos tem um mundo cognitivo próprio dentro de si mesmo e sua relação com as partes que são impactadas, sem relacionar-se, a priori, com os outros pedidos. Cada qual conterá a sua própria admissibilidade, as suas próprias preliminares, prejudiciais, questões de fato e de mérito, até culminar na possibilidade de julgar o seu mérito, especificadamente ${ }^{21}$.

Todo esse caminho existente cognitivo para cada um dos pedidos pode andar em conjunto e até dividir cognições com outros pedidos, como, por exemplo, uma preliminar ou uma prejudicial pode ser comum a dois pedidos, como uma prescrição, servindo a resolução desta para ambos os pedidos.

O normal, procedimentalmente, será o andamento conjunto de todos os pedidos e suas cognições para culminar na prolação de uma só sentença, com o cuidado procedimental de que as fases respeitem cada uma das complexidades objetivas do processo, proporcionando o contraditório para todos os momentos, podendo produzir

resultado tenha sido positivo - isto é, que o recurso seja admissível -, cumpre decidir a matéria impugnada através deste, para acolher a impugnação, caso fundada, ou rejeitá-la, caso infundada (juízo de mérito)." BARBOSA MOREIRA, José Carlos. O novo processo civil brasileiro. $20^{\circ}$. ed. Rio de Janeiro: Forense, 2000. p. 115.

21 Para Dinamarco, seguindo Liebman, a autonomia dos capítulos da sentença é evidente, com a necessidade de verificação de dois pontos: "a) o da possibilidade de que cada um deles fosse objeto de um processo separado e b) o da regência de cada um por pressupostos próprios, que não se confundem necessariamente nem por inteiro com os pressupostos dos demais." DINAMARCO, Cândido Rangel. Capítulos de sentença. $3^{\text {a }}$. ed. São Paulo: Malheiros, 2008. p. 41. 
Rio de Janeiro. Ano 15. Volume 22. Número 3. Setembro a Dezembro de 2021

Periódico Quadrimestral da Pós-Graduação Stricto Sensu em Direito Processual da UERJ

Patrono: José Carlos Barbosa Moreira (in mem.). ISSN 1982-7636. pp. 1067-1124

www.redp.uerj.br

provas específicas de cada relação, deixando o processo pronto para ser julgado como um todo $^{22}$, com todos os pedidos sendo julgados em uma só sentença a ser prolatada.

No entanto, dada a existência dessa complexidade objetiva no processo, apesar da separação cognitiva entre questões de admissibilidade e mérito, há a possibilidade da cisão cognitiva entre as parcelas do processo que forem estanques, caso se configure uma situação processual que assim permita a cisão, com o fracionamento decisório para tanto.

Portanto, se num processo existem dois pedidos, com duas lógicas decisórias apartadas, há a total possibilidade de julgar em determinado momento um pedido, com uma parcela decisória desde já e deixar o restante que ainda não é possível de julgamento para momento posterior ${ }^{23}$.

Essa é a cisão cognitiva inerente ao próprio processo objetivamente complexo ${ }^{24}$.

\subsection{A positivação da cisão cognitiva e a decisão parcial no CPC/2015}

No CPC/2015, houve a positivação de cada uma dessas possibilidades de julgamento parcial - arts. 354, parágrafo único e 356 do CPC, com a cindibilidade da demanda e da sua concepção decisória, porém seria necessária a positivação para tanto? $\mathrm{Na}$ concepção do ordenamento anterior, não havia nada sobre a disposição de tal cisão, com a utilização do que Liebman defendia de que qualquer cindibilidade iria em sentido contrário à teoria da unicidade da sentença e somente seria possível com a autorização legal ${ }^{25}$.

22 A teoria da unicidade não sai da sentença, sendo totalmente possível e viável, seja na última redação do código revogado ou no CPC/2015, a possibilidade de uma sentença que concentre todos os capítulos decisórios. Todavia, não é obrigatório que assim seja, apesar de que, inicialmente, o juízo busque, procedimentalmente, essa decisão completa. Nesse sentido: DIAS, Jean Carlos. A reforma do CPC (LGL\1973\5) e o fim da teoria da unidade da sentença - Lei 11.232/2005. Revista Dialética de Direito Processual. Vol. 40, p. 79-84, São Paulo: Dialética, Jul/2006. p. 81.

23 "Uma fruta que está madura não precisa esperar o amadurecimento da outra, ainda verde, para ser colhida." DIDIER JR., Fredie. Inovações na antecipação dos efeitos da tutela e a resolução parcial do mérito. Revista de Processo. Vol. 110, Ano 28, p. 225-251, São Paulo: Ed. RT, abr/jun/2003. p. 232.

24 Sobre a divisão entre quais os capítulos possíveis na sentença e na demanda que possibilitam a cisão: “a divisão pode ser realizada da seguinte forma: a) capítulo referente aos pressupostos processuais de admissibilidade do julgamento de mérito; b) diferentes capítulos decidindo no mérito diferentes pedidos; c) nos pedidos decomponíveis a existência de dois capítulos quando do julgamento de parcial procedência; d) capítulo referente ao custo financeiro do processo". DINAMARCO, Cândido Rangel. Instituições de direito processual civil. Vol. III. $3^{\text {a }}$. ed. São Paulo: Malheiros, 2003. p. 665.

25 Sobre a unicidade e a necessidade de norma para a sua excecionalidade, na visão de Liebman, destacada por Dinamarco: "tal é o princípio da unidade estrutural da sentença, que só pode ser contrariado quando uma específica norma de direito o autorizar (Liebman).” DINAMARCO, Cândido Rangel. Instituições de direito processual civil. Vol. III. $3^{\text {a }}$. ed. São Paulo: Malheiros, 2003. p. 700/701. 
Rio de Janeiro. Ano 15. Volume 22. Número 3. Setembro a Dezembro de 2021

Periódico Quadrimestral da Pós-Graduação Stricto Sensu em Direito Processual da UERJ

Patrono: José Carlos Barbosa Moreira (in mem.). ISSN 1982-7636. pp. 1067-1124

www.redp.uerj.br

A doutrina já se debruçava, no ordenamento anterior, ainda que timidamente, sobre o tema, com a defesa de que o processo objetivamente complexo já possibilitava essas cisões $^{26}$, independentemente de autorização legal ${ }^{27}$.

Depois de duas alterações legais, primeiro com a inclusão do $\S 6^{\circ}$ ao art. 273 do CPC $/ 73^{28}$, pela Lei $n^{\circ} 10.444 / 02$ e depois a alteração da conceituação de sentença, com a redação do art. 162, $\S 1^{\circ}$ do CPC/73 modificada pela Lei $\mathrm{n}^{\circ} 11.232 / 05$, o estudo da cisão cognitiva e cisão de decisões ${ }^{29}$, quebrando a unicidade da sentença, com a possibilidade de prolação de sentenças parciais, passou a ser alvo de maior aprofundamento e, consequentemente, de mais controvérsias ${ }^{30}$, apesar de não ser um assunto que tenha se esgotado, com resistência pela sua ausência de norma autorizante e dificuldade de

26 Já admitindo a cisão cognitiva por causa do indeferimento da inicial no ordenamento revogado: "O indeferimento pode ser total ou parcial.” BARBOSA MOREIRA, José Carlos. O novo processo civil brasileiro. $20^{\circ}$. ed. Rio de Janeiro: Forense, 2000. p. 25.

27 No sentido de que já era possível a cisão cognitiva e a prolação de decisões parciais, ainda no ordenamento passado, mesmo na ausência de positivação: ARAÚJO, José Henrique Mouta. A resolução parcial de mérito e a coisa julgada progressiva: reflexos no sistema processual como forma de assegurar a brevidade da prestação jurisdicional. Belém, PA, 2004. 302 p. Tese (Doutorado). Universidade Federal do Pará. Programa de Pós-Graduação em Direito; NOGUEIRA, Gláucia Assalin. O julgamento parcial: possibilidade de cisão do julgamento de mérito relativamente à parte incontroversa da demanda. São Paulo, SP, 2009. 191 p. Dissertação (Mestrado). Universidade de São Paulo. Programa de Pós-Graduação em Direito; AMBRIZZI, Tiago Ravazzi. Julgamento fracionado do mérito no processo civil brasileiro. São Paulo, SP, 2014. 231 p. Dissertação (Mestrado). Universidade de São Paulo. Programa de Pós-Graduação em Direito; BARBOSA, Bruno Valentim. Julgamentos parciais de mérito no processo civil individual brasileiro. São Paulo, SP, 2013. 161 p. Dissertação (Mestrado). Universidade de São Paulo. Programa de Pós-Graduação em Direito; OLIVEIRA FILHO, Silas Dias de. Julgamento fracionado do mérito e implicações no sistema recursal. São Paulo, SP, 2013. 256 p. Dissertação (Mestrado). Universidade de São Paulo. Programa de Pós-Graduação em Direito; CORREIA FILHO, Antonio Carlos Nachif. Julgamentos parciais no processo civil. São Paulo, SP, 2015. 176 p. Dissertação (Mestrado). Universidade de São Paulo. Programa de Pós-Graduação em Direito.

28 Nesse sentido: DOTTI, Rogéria Faria. A tutela antecipada em relação à parte incontroversa da demanda. 2a. ed. São Paulo: Ed. RT, 2003; CUNHA, Leonardo José Carneiro da. O $\S 6^{\circ}$ do art. 273 do CPC: Tutela Antecipada Parcial ou Julgamento Antecipado Parcial da Lide? Revista Dialética de Direito Processual. n. 1, p. 109-126, São Paulo: Dialética, Abril/2003; DIDIER JR., Fredie. Inovações na antecipação dos efeitos da tutela e a resolução parcial do mérito. Revista de Processo. Vol. 110, Ano 28, p. 225-251, São Paulo: Ed. RT, abr/jun/2003; MARINONI, Luiz Guilherme. Abuso de defesa e parte incontroversa da demanda. São Paulo: Ed. RT, 2007.

29 Toda essa evolução do ordenamento processual, desde o revogado até o panorama atual da cisão cognitiva e o fracionamento decisório no CPC/2015 estarão melhor delineado no capítulo quatro, com a análise da evolução histórica mais detalhadamente.

30 A defesa da impossibilidade de cisão no $\mathrm{CPC} / 73$ : "absolutamente contrária ao sistema, porque todas as questões relacionadas ao mérito devem ser julgadas em um ato só.” DINAMARCO, Cândido Rangel. Instituições de direito processual civil. Vol. III. $3^{\text {a }}$. ed. São Paulo: Malheiros, 2003. p. 668. 
Revista Eletrônica de Direito Processual - REDP.

Rio de Janeiro. Ano 15. Volume 22. Número 3. Setembro a Dezembro de 2021

Periódico Quadrimestral da Pós-Graduação Stricto Sensu em Direito Processual da UERJ

Patrono: José Carlos Barbosa Moreira (in mem.). ISSN 1982-7636. pp. 1067-1124

www.redp.uerj.br

compreensão, o que fez a jurisprudência não caminhar nesse sentido ${ }^{31}$, ao menos diante do

ordenamento anterior revogado.

Dessa maneira, de modo geral, a cisão cognitiva e o fracionamento decisório

existente no CPC/2015, estão dispostos no art. 354, parágrafo único e no art. 356, ambos

do CPC.

A primeira hipótese trata de uma cisão sobre as questões de admissibilidade do

processo. Cada pedido de um processo objetivamente complexo detém uma

31 Ainda sobre a égide do CPC/73, em 2015 o STJ teve a oportunidade de julgar um Recurso Especial sobre o tema da cisão cognitiva e a possibilidade de cindir o processo em quantas decisões fossem necessárias, dada a possibilidade de julgamento com as resoluções de questões de fato assim autorizando. Todavia, o entendimento foi no sentido de não adotar a quebra da unicidade da sentença e negar recurso especial para tanto, vejamos: RECURSO ESPECIAL N ${ }^{\circ}$ 1.281.978 - RS (2011/0224837-2) EMENTA RECURSO ESPECIAL. PROCESSO CIVIL. REFORMA PROCESSUAL. LEI No 11.232/2005. ADOÇÃO DO PROCESSO SINCRÉTICO. ALTERAÇÃO DO CONCEITO DE SENTENÇA. INCLUSÃO DE MAIS UM REQUISITO NA DEFINIÇÃO. CONTEÚDO DO ATO JUDICIAL. MANUTENÇÃO DO PARÂMETRO TOPOLÓGICO OU FINALÍSTICO. TEORIA DA UNIDADE ESTRUTURAL DA SENTENÇA. PROLAÇÃO DE SENTENÇA PARCIAL DE MÉRITO. INADMISSIBILIDADE. CISÃO INDEVIDA DO ATO SENTENCIAL. ART. 273, $6^{\circ}$, DO CPC E NOVO CÓDIGO DE PROCESSO CIVIL. INAPLICABILIDADE. 1. Cinge-se a controvérsia a saber se as alterações promovidas pela Lei $n^{\circ} 11.232 / 2005$ no conceito de sentença (arts. 162, § 1º, 269 e 463 do CPC) permitiram, na hipótese de cumulação de pedidos, a prolação de sentença parcial de mérito, com a resolução definitiva fracionada da causa, ou se ainda há a obrigatoriedade de um ato único para resolver integralmente o mérito da lide, pondo fim a uma fase do processo. 2. A reforma processual oriunda da Lei $n^{\circ} 11.232 / 2005$ teve por objetivo dar maior efetividade à entrega da prestação jurisdicional, sobretudo quanto à função executiva, pois o processo passou a ser sincrético, tendo em vista que os processos de liquidação e de execução de título judicial deixaram de ser autônomos para constituírem etapas finais do processo de conhecimento; isto é, o processo passou a ser um só, com fases cognitiva e de execução (cumprimento de sentença). Daí porque houve a necessidade de alteração, entre outros dispositivos, dos arts. 162, 269 e 463 do CPC, visto que a sentença não mais "põe fim" ao processo, mas apenas a uma de suas fases. 3. Sentença é o pronunciamento do juiz de primeiro grau de jurisdição (i) que contém uma das matérias previstas nos arts. 267 e 269 do CPC e (ii) que extingue uma fase processual ou o próprio processo. Em outras palavras, sentença é decisão definitiva (resolve o mérito) ou terminativa (extingue o processo por inobservância de algum requisito processual) e é também decisão final (põe fim ao processo ou a uma de suas fases). Interpretação sistemática e teleológica, que melhor se coaduna com o atual sistema lógicoprocessual brasileiro. 4. A novel legislação apenas acrescentou mais um parâmetro (conteúdo do ato) para a identificação da decisão como sentença, pois não foi abandonado o critério da finalidade do ato (extinção do processo ou da fase processual). Permaneceu, dessa forma, no Código de Processo Civil de 1973 a teoria da unidade estrutural da sentença, a obstar a ocorrência de pluralidade de sentenças em uma mesma fase processual. 5. A sentença parcial de mérito é incompatível com o direito processual civil brasileiro atualmente em vigor, sendo vedado ao juiz proferir, no curso do processo, tantas sentenças de mérito/terminativas quantos forem os capítulos (pedidos cumulados) apresentados pelo autor da demanda. 6. Inaplicabilidade do art. $273, \S 6^{\circ}$, do CPC, que admite, em certas circunstâncias, a decisão interlocutória definitiva de mérito, visto que não foram cumpridos seus requisitos. Ademais, apesar de o novo Código de Processo Civil (Lei no 13.105/2015), que entrará em vigor no dia 17 de março de 2016, ter disciplinado o tema com maior amplitude no art. 356, permitindo o julgamento antecipado parcial do mérito quando um ou mais dos pedidos formulados na inicial ou parcela deles (i) mostrar-se incontroverso ou (ii) estiver em condições de imediato julgamento, não pode incidir de forma imediata ou retroativa, haja vista os princípios do devido processo legal, da legalidade e do tempus regit actum. 7. Recurso especial não provido. 
Rio de Janeiro. Ano 15. Volume 22. Número 3. Setembro a Dezembro de 2021

Periódico Quadrimestral da Pós-Graduação Stricto Sensu em Direito Processual da UERJ

Patrono: José Carlos Barbosa Moreira (in mem.). ISSN 1982-7636. pp. 1067-1124

www.redp.uerj.br

admissibilidade própria e peculiar, com o dever do juízo em analisar cada questão sobre o cumprimento devido de cada pressuposto. Quando proceder essa análise e, porventura, um dos pressupostos não estiver presente, sem a possibilidade de sanabilidade, o juízo deve decidir pela extinção, dada a inviabilidade do prosseguimento do processo.

Todavia, se essa ausência de preenchimento dos pressupostos for de um vício que somente impacta parcela do processo, o juízo deve decidir pela extinção parcial, extinguindo aquele pedido ou excluindo uma parte que não deveria ali constar, sem atingir a totalidade do processo, realizando uma autêntica cisão cognitiva.

De mesmo modo, numa segunda hipótese, quando analisar que um dos pedidos do processo está apto a ser respondido antes dos demais também existentes no pleito do autor, o juízo deve, desde logo, decidir o que é possível, cindindo o processo e prosseguindo com a parcela que não for possível decidir naquele momento.

Se no ordenamento processual anterior não havia tal previsão positivada, com a necessidade de construção doutrinária para tanto, com a defesa de que a complexidade objetiva já autorizaria essa cisão em situações processuais que os fatos e ocorrências concretas possibilitassem essas cisões desse porte, o CPC/2015 possibilita positivadamente essas cisões, vislumbrando que a análise das questões podem levar a cognição ser cindida, tanto nas questões de admissibilidade quanto no próprio objeto litigioso do processo, em ambos com a viabilidade de julgamento de modo parcial.

No entanto, importante diferenciar as cisões, uma vez que, apesar de levarem a cognições e decisões parciais ${ }^{32}$, são motivadas por diretrizes totalmente diversas, não sendo correto enquadrá-las como idênticas, o que importa em diferenciá-las para entender a espécie de cisão que ocorre em cada situação.

\subsubsection{A decisão parcial sem mérito: a cisão cognitiva por falta de pressuposto processual de parcela do processo}

32 Se a cognição pode ser dividida mediante os capítulos decisórios, a processualística pode dividir as decisões entre totais e parciais. No CPC/73: SCARPARO, Eduardo Kochenborger. Sentenças parciais? Considerações a partir de reforma do art. 162, $\S 1^{\circ}$, do CPC. Revista de Processo. n. 148, Ano 32, p. 153168, São Paulo: Ed. RT, Jun/2007. No CPC/2015: DIDIER JR., Fredie. Comentários ao art. 485. In: CABRAL, Antônio do Passo; CRAMER, Ronaldo (Coord.). Comentários ao novo Código de Processo Civil. Rio de Janeiro: Forense, 2015. 
No tocante às decisões interlocutórias parciais sem mérito, o art. 354, parágrafo único do CPC é a sua norma autorizante, possível no momento em que o juízo analisa os pressupostos processuais, geralmente no momento do saneamento e organização do processo, com a percepção de que existe alguma questão processual com vício intransponível $^{33}$ e, assim, decide parcialmente pela extinção do processo, com o prosseguimento da parcela não alcançada materialmente por esse pressuposto processual não cumprido e que impede a continuidade dessa parcela.

Para entender essa cisão e a possibilidade da prolação de um julgamento parcial sem mérito, esta ocorrerá quando houver uma pluralidade de partes ou cumulação de pedidos e a ausência de pressupostos processuais somente incorrer em um deles: (i) falta pressuposto processual para autorizar o prosseguimento sobre determinado pedido, com intransponibilidade do vício; (ii) falta pressuposto processual para autorizar o prosseguimento de determinada parte, em um dos polos do processo ${ }^{34}$.

Em qualquer dessas hipóteses, a cisão cognitiva é possível pelo reconhecimento de uma questão de admissibilidade não superável, que tem uma parcela intransponível, sem alcançar a integralidade do processo, o que permite cindir o processo e as cognições

33 Se uma demanda não for complexa, somente com um pedido, uma vez não preenchidos os pressupostos processuais, a sentença será para extinção. Todavia, de modo diverso, se for objetivamente complexa, essa decisão pode ser parcial, atingindo somente o pedido que dependa daquele pressuposto viciado, caso o vício seja também específico daquela parcela da demanda. "Se o juiz rejeita essa pretensão e extingue o processo sem julgamento do mérito, provavelmente não haverá cisão alguma, sendo a sentença preenchida exclusivamente por esse teor extintivo do processo." DINAMARCO, Cândido Rangel. Capítulos de sentença. $3^{\text {a }}$. ed. São Paulo: Malheiros, 2008. p. 52.

34 Por exemplo, a possibilidade da exclusão de litisconsorte, como veremos detalhadamente a posterior, será na percepção na cognição dos pressupostos da demanda que uma das partes - ativa ou passiva - não é legítima para figurar como autora ou ré, sem relação com o direito ali vindicado, perfazendo uma decisão que prima por excluir aquele determinado litisconsorte e continuar com o objeto da demanda, com o mesmo mérito, somente alterando - com a exclusão - um dos polos. "Exclusão de litisconsorte (VII): a ilegitimidade ad causam é matéria cognoscível por provocação do interessado e também ex officio (art. 337, XI e § 5.o) e pode ser reconhecida apenas quanto à parte dos litigantes, de modo a não extinguir o processo por completo (art. 485, II), mas permitir que o processo continue a tramitar sem o litisconsorte desprovido de legitimidade. Coerente com a nova definição de sentença acolhida no art. 203 , § 1.o, trata-se de decisão interlocutória e, por força do dispositivo ora em comento, agravá- vel. Por fim, entendo que não caberá agravo de instrumento nos seguintes casos: (a) contra a decisão que rejeita a alegação de ilegitimidade e mantém o litisconsorte na relação processual; (b) contra a decisão que procede à exclusão do réu original e a sua troca por outro sujeito, nos termos dos arts. 338 e 339 , pois não se trata propriamente de "exclusão de litisconsorte" e, ademais, ambos os dispositivos pressupõem concordância do autor (haverá, nesse caso, preclusão lógica, mercê do art. 1.000); (c) recurso interposto pelo autor apenas contra o capítulo da decisão que fixa as verbas honorárias em favor do réu que foi citado, contratou advogado, se defendeu e restou excluído;" SICA, Heitor Vitor Mendonça. Comentário ao art. 1.015. In: STRECK, Lenio Luiz; NUNES, Dierle; CUNHA, Leonardo (orgs.). Comentários ao código de processo civil. $2^{\mathrm{a}}$. ed. São Paulo: Saraiva, 2017. p. 1.375 . 
Rio de Janeiro. Ano 15. Volume 22. Número 3. Setembro a Dezembro de 2021

Periódico Quadrimestral da Pós-Graduação Stricto Sensu em Direito Processual da UERJ

Patrono: José Carlos Barbosa Moreira (in mem.). ISSN 1982-7636. pp. 1067-1124

www.redp.uerj.br

pertinentes somente sobre o determinado vício no devido impacto que ele proporciona aos elementos objetivos e subjetivos do processo, sem extingui-lo totalmente, mas somente nos limites do que o vício alcança ${ }^{35}$.

A cisão cognitiva existente, nessa hipótese, está em retirar parcela do processo que não alcançou viabilidade processual de ser julgado ou retirar da relação jurídica uma parte que não demonstrou motivos autorizantes de sua permanência na litispendência, prolatando, em qualquer das hipóteses, uma decisão interlocutória parcial sem mérito.

\subsubsection{A decisão parcial com mérito: a cisão cognitiva da resposta efetiva da jurisdição}

De outro modo funciona a cisão que envolve o mérito.

Há uma divisão do que se cumulou no mesmo processo, uma bipartição do próprio exercício pela jurisdição. Se um processo se tornou objetivamente complexo pela existência de múltiplas relações existentes, com diversos pedidos ou diversas partes, essa cisão cognitiva tem a função de dividir o próprio processo, julgando a parcela do mérito que já puder ser resolvida, nos moldes da dicção do art. 356 do CPC.

Numa situação em que parcela do mérito já encontra-se com a possibilidade de prolação de decisão imediata de mérito e o restante ainda não, com pedidos ainda com necessidade de instrução e definição probatória, é dever do juízo, no momento em que analisar todo o processo para saneá-lo e organizá-lo, se tiver a percepção de que parcela do processo deverá prosseguir para a instrução probatória - ou qualquer outra situação correlata $^{36}$ - e que determinada parcela do processo já preenche todas as condições processuais e cognitivas para ser julgada, deve, consequentemente, prolatar uma decisão

35 Sobre os pontos processuais, há um capítulo próprio sobre os pressupostos processuais. De modo geral, há, diante da análise do cumprimento ou não dos pressupostos, a possibilidade do resultado negativa (extinção da demanda) ou positivo (admissibilidade para o julgamento de mérito). No entanto, num processo objetivamente complexo, cada capítulo de mérito tem os seus próprios pressupostos, sendo possível, para tanto, uma extinção parcial: "Nessas hipóteses o preceito decisório imperativo a respeito de toda a matéria processual é um só, a saber: a) a extinção processual por falta de um ou mais dos pressupostos para prosseguir; ou b) a afirmação de que todos os pressupostos estão presentes e, portanto, o julgamento do mérito é admissível, perdurando todo o processo." DINAMARCO, Cândido Rangel. Capítulos de sentença. $3^{\text {a }}$. ed. São Paulo: Malheiros, 2008. p. 41.

36 O normal da prolação de uma decisão parcial com mérito será em conjunto com o saneamento, uma vez que é o momento imaginado pelo ordenamento para que se verifique as providências preliminares do juízo. Todavia, é possível que ocorra em outros momentos decisórios. 
definitiva, a qual não será uma sentença, e sim uma decisão interlocutória parcial de mérito, fracionando o processo em seu viés decisório.

A cisão cognitiva proposta pelo ordenamento nesse tocante é uma cisão de pedidos constante na demanda, uma vez que consta mais de um pedido do processo dada a cumulação de pretensões do autor, o que importa no fracionamento do processo, com uma decisão que possibilita uma desacumulação de pedidos existentes naquele processo.

Os pedidos que envolvem o objeto litigioso do processo pretendido pelo autor sofrerão uma cisão em sua cognição e procedimentalidade, com o julgamento da parcela possível nesse determinado momento interlocutório e a postergação do restante do objeto litigioso - demais pedidos - para a análise após a instrução probatória do que restou materialmente no processo, justamente pela necessidade de definição cognitiva sobre questões de fatos atinentes a estes pontos do mérito, para posterior encerramento da fase cognitiva e prolação da sentença.

A parcela do processo que não detém necessidade de instrução ou de discussão sobre as questões de fatos será passível da prolação de uma decisão interlocutória parcial de mérito.

\section{AS QUESTÕES DE FATO NUM PROCESSO COMPLEXO OBJETIVAMENTE}

Obviamente que essas duas possibilidades de cisão cognitiva - parcial sem a resolução do mérito e com a resolução do mérito - são diversas e a primeira classificação que deve ser feita com base no que o próprio ordenamento enquadra como diversidade na decisão interlocutória, sendo possível, portanto, o fracionamento decisório com conteúdo resolutivo de mérito ou sem resolubilidade do mérito ${ }^{37}$.

No entanto, outros pontos de análise são necessários para o devido entendimento sobre as decisões interlocutórias parciais e quais as espécies de cisões cognitivas, sobre os impactos em questões de admissibilidade, preliminares e prejudicais, prévias ou principais, de fato e de direito, e, ainda, o grau de independência dessas questões em relação àquelas que ainda serão julgadas, com os devidos reflexos processuais e procedimentais que podem ocorrer.

37 Versando também sobre a decisão parcial sem mérito: MEIRELES, Edilton. Julgamento antecipado parcial do mérito. Revista de Processo. Vol. 252, Ano 41, p. 133-146, São Paulo: Ed. RT, fev/2016. 
Para a construção da decisão parcial e da cisão cognitiva e processual, há a necessidade de presença de requisitos autorizantes e estas são interligadas com as questões que devem ser enfrentadas, sobretudo as questões de fato.

A decisão parcial somente será possível quando uma parcela da jurisdição já detém a possibilidade de resolver as questões de fato a ela atinente ou já for tida como incontroversa aquela concretude fática. Há, notadamente, uma dificuldade de distinção sobre questões de fato das questões de direito, com o quanto que elas estão umbilicalmente $^{38}$ interligadas e na dificuldade - ou talvez impossibilidade $^{39}$ - de separálas, principalmente na impugnabilidade do ato decisório ${ }^{40}$.

Para o desenvolvimento da consequência da complexidade objetiva do processo e as questões de fato, entende-se aqui como plausível a divisão entre questão de fato e de direito como possível, apesar de difícil, em dois polos: (i) a existência de controvérsia sobre algum ponto de fato necessário para a subsunção; (ii) a necessidade de instrução probatória sobre essa questão para possibilitar a subsunção.

A atividade do juízo se dividirá, ao menos numa cronologia procedimental, em um momento para definição das questões de fato, com a necessidade, ou não, da instrução probatória e, após a definição destas, o início da resolução das questões de direito, com a subsunção ${ }^{41}$ pertinente para a resolução destas questões e a aptidão para a decisão do processo, aquela que terá o condão de formar coisa julgada.

Enquanto o juízo estiver com a atribuição em definir a correta - ou mais provável narrativa fática, as questões cognitivas serão predominantemente fáticas, ainda que delineadas pelo direito e, depois dessa fase, com tais resoluções já realizadas dado o enfrentamento cognitivo pelo juízo, a atividade judicante passa a debruçar-se sobre as

38 Sobre a relação entre questão de fato e questão de direito, com as influências sobre a existência, ou não, de controvérsia sobre os fatos: "Todo direito subjetivo decorre do binômio norma-fato. O conhecimento é problema do juiz. Esta, todavia, produzirá determinado efeito se e quando presente estiver o fato sobre o qual incide, cumprindo às partes, conforme o caso, o ônus de provar o fato controvertido no processo." MACHADO, Hugo de Brito. As questões de fato e a sentença de mérito. Revista Dialética de Direito Processual. Vol. 96. p. 65-71. São Paulo, mar/2011. p. 68.

39 No sentido de predominância de um sobre o outro, mas nunca de isolamento: ALVIM, Teresa Arruda. Distinção entre questão de fato e questão de direito para fins de cabimento de recurso especial. Revista de Processo. vol. 92. p. 52-70. São Paulo: Ed. RT, 1998. p. 53.

40 Sobre essa discussão no âmbito recursal superior: FONSECA, João Francisco Naves da. Exame dos fatos nos recursos extraordinário e especial. São Paulo, SP, 2010. 192 p. Dissertação (Mestrado). Universidade de São Paulo. Programa de Pós-Graduação em Direito.

41 DIDIER JR., Fredie. Objeto da cognição judicial. Revista Dialética de Direito Processual. Vol. 6, p. $12-$ 23, São Paulo: Dialética, set/2003. p. 15. 
Rio de Janeiro. Ano 15. Volume 22. Número 3. Setembro a Dezembro de 2021

Periódico Quadrimestral da Pós-Graduação Stricto Sensu em Direito Processual da UERJ

Patrono: José Carlos Barbosa Moreira (in mem.). ISSN 1982-7636. pp. 1067-1124

www.redp.uerj.br

questões de direito, justamente com base no suporte fático concreto outrora decidido, desenvolvendo-se com predominância jurídica, apesar do arcabouço de fatos existentes e fixados.

De certa maneira, a questão de fato, por mais complexa que seja de cindi-la da questão de direito, ela é antecedente a esta ${ }^{42}$, com a necessidade de uma cognição prévia ${ }^{43}$ num caminho anterior a ser seguido para conceder a aptidão à resolução da questão de direito, apesar de auxiliá-la e com sutil aparência de caminhar conjuntamente.

Posta essa distinção como possível, a questão de fato é importante para o desenvolvimento da pretensão em juízo, diante da existência de pontos fáticos contraditados $^{44}$ pelas narrativas do autor e do réu ou pela impossibilidade de presunção de veracidade $^{45}$, com o juízo prosseguindo com a instrução probatória em todos esses casos.

Não há demanda que não se baseie em uma narrativa fática, com total potencial para que possa se transformar em uma questão de fato a ser resolvida, pelo contraditório inerente aos acontecimentos de fato, caso o réu se contraponha ao que foi narrado pelo autor $^{46}$. Ou seja, não há o que se demandar sem narrativas de fatos, contudo pode haver

42 Greco fala exatamente sobre essa antecedência sobre a questão de fato à questão de direito, justamente pela necessidade de comprovar a situação fática controvertida, para somente após discutir-se a questão jurídica. "De nada adianta o direito em tese ser favorável a alguém se não consegue demonstrar que se encontra numa situação que permite a incidência da norma." GRECO FILHO, Vicente. Direito processual civil brasileiro. Vol II. 16a . ed. São Paulo: Saraiva, 2003. p. 181.

43 "para ser objeto de prova, o fato precisa ser controvertido, isso é, afirmado por uma parte e negado por outra." WAMBIER, Luiz Rodrigues; TALAMINI, Eduardo. Curso avançado de processo civil. vol. 2, 5. ed. São Paulo: Ed. RT, 2016. p. 242.

44 "aqueles que são afirmados por uma parte e impugnados pela parte contrária. (...) Todo fato relevante à causa, que influa no convencimento do juiz, precisa ser provado.” ALVIM, Arruda. Novo contencioso cível no CPC. São Paulo: Ed. RT, 2016. p. 242.

45 Sobre a presunção da veracidade, não é automática, não é absoluta, com a necessidade de análise sobre a possibilidade de ocorrência: "Uma das características da praesumptionis juris, está no seu efeito: dispensa do ônus da prova aquele que as tem em seu favor. (...) É preciso que se entenda essa regra nos seus devidos limites (...) Quem a invoca deverá necessariamente demonstrar que está na situação de poder invocá-la. Por ser legal, a presunção não deixar de ser uma presunção, e, portanto, constituída de três elementos: $1^{\circ}$.) o fato conhecido; $2^{\circ}$.) o fato desconhecido; $3^{\circ}$.) o nexo de causalidade entre o ato conhecido e o fato desconhecido. $\mathrm{O}$ fato desconhecido é havido como provado pela lei, que também tem como reconhecido e preestabelecido o nexo de causalidade, mas isto e aquilo se verificam quando quem invoca a presunção faça provado o fato do qual ela dimana, isto é, o fato conhecido." MALUF, Carlos Alberto Dabus. As presunções na teoria da prova. Revista de Processo. Vol. 24, Ano 6, p. 62-88, São Paulo: Ed. RT, Out/Dez/1981. p. 77.

46 "Assim, o juiz, ao julgar, deve fazer três indagações: a) se os fatos se passaram como afirmado pelo demandante ou não; b) que norma(s) jurídicas(s) disciplinam os fatos; e c) quais as consequências determinadas pela(s) norma(s) jurídica(s). Por tal razão, costuma-se, para fins didáticos, equiparar a atividade do juiz a um silogismo: há a subsunção de uma premissa menor (os fatos) a uma premissa maior (a regra jurídica)." YOSHIKAWA, Eduardo Henrique de Oliveira. A distinção entre prescrição e 
demanda sem questão de fato a ser resolvida, pela hipótese de falta de argumentação contraditória do réu sobre tal ponto, passando-se automaticamente para a subsunção da norma diante desse suporte fático já delineado como incontroverso.

\subsection{A pluralidade das questões de fato num processo complexo objetivamente}

A existência de uma pluralidade de relações jurídicas no processo, seja por diversas partes nos polos, seja pela cumulação de pedidos, não pressupõe que haja uma pluralidade de questões de fato. Pode ocorrer um processo complexo objetivamente que dependa somente de uma questão de fato para solucionar todas as bases jurídicas a serem decididas, ainda que seja em caráter excepcional.

Ou seja, um processo objetivamente complexo não significa que seja faticamente complexo, dependendo obviamente da disposição da narrativa fática realizada pelas partes em suas postulações. Se houver pluralidades de partes ou pedidos e uma só questão de fato cerne para a cognição do processo, por mais complexa que seja essa pluralidade de relações a serem respondidas pelo juízo, estas dependerão de somente uma definição sobre pontos fáticos, importando em um só ato decisório, numa inviabilidade da cisão cognitiva e o fracionamento do processo em dois momentos decisórios.

Um exemplo seria uma ação sobre a alegação de inscrição indevida no cadastro de inadimplentes com pedidos cumulados: (i) declaração de inexistência de débito; (ii) obrigação de fazer para a retirada do nome do cadastro citado. Para ambos os pedidos serem julgados somente há a necessidade da resolução de uma questão de fato: a controvérsia se a inscrição é devida ou indevida.

Com a resolução desta questão de fato, o juízo pode julgar tanto a declaração de que o débito é existente ou não quanto se há ou não obrigação de fazer para retirar o nome do cadastro de inadimplentes. Logo, não há como cindir o processo para uma decisão sobre um pedido em um momento processual, com a postergação do outro pedido para a sentença, justamente por ambos dependerem de somente uma resolução fática. Uma vez esta determinada questão de fato resolvida, todos os pedidos podem ser julgados na sentença, num único ato decisório, sem cindibilidade. 
Por outro lado, num processo complexo objetivamente, com diversas relações jurídicas a serem solucionadas, há a possibilidade de existência de uma pluralidade de questões de fato, diante de uma igual complexidade dos acontecimentos fáticos narrados pelas partes em suas postulações e com a necessidade consequente de que todas essas questões sejam enfrentadas para que se possa realizar a cognição judicial, com a posterior subsunção.

Numa situação destas, há a confluência entre um processo complexo objetivamente e uma complexidade de questões de fato, tornando ainda mais complexa a cognição judicial a ser realizada, contudo abrindo a viabilidade permissiva de uma possível cisão cognitiva e fracionamento decisório, caso se configurem os requisitos pertinentes para o julgamento seja fracionado, com a possibilidade de momentos decisórios separados na prestação da jurisdição.

Dessa maneira, diante de uma situação processual como essa, com pluralidade de partes ou pedidos e igualmente plural em suas questões de fato, abre-se a possibilidade de que uma destas questões contenha resolubilidade desde logo, seja por ser incontroversa (motivo mais comum), seja pelas partes terem possibilitado uma dispensa de produção de prova, ambas viabilizando com a abertura de possibilidade de decisão sobre esta questão de fato e a análise se alguma das relações jurídicas existentes no processo dependa somente dessa determinada questão de fato.

Obviamente que não é a mera resolubilidade de uma das questões de fato que permite a cisão cognitiva e o fracionamento decisório, mas uma série de requisitos, com a necessidade de análise entre as interligações de cada questão de fato e a cognição judicial sobre cada uma das relações jurídicas a serem resolvidas, seja pela pluralidade de partes, seja pela pluralidade de pedidos.

\section{A PLURAlidade das QUeSTões de FATO E A SUA RESOlUbilidade PARCIAL COMO REQUISITOS PARA A POSSIBILIDADE DA DECISÃo PARCIAL}


Rio de Janeiro. Ano 15. Volume 22. Número 3. Setembro a Dezembro de 2021

Periódico Quadrimestral da Pós-Graduação Stricto Sensu em Direito Processual da UERJ

Patrono: José Carlos Barbosa Moreira (in mem.). ISSN 1982-7636. pp. 1067-1124

www.redp.uerj.br

Quando um processo for complexo objetivamente, seja pela cumulação de pedidos, seja pela pluralidade de partes em um dos polos, o processo será dividido em capítulos para serem resolvidos de modo autônomo ${ }^{47}$, nos moldes da teoria dos capítulos de sentença.

Esses capítulos são divididos entre a admissibilidade e mérito, ou, ainda, internamente dentro do próprio mérito, com relações autônomas entre estes capítulos, dada a possibilidade do juízo em analisar de maneira específica e isolada cada um desses capítulos $^{48}$, com respostas igualmente específicas e separadas.

No tocante à divisão entre o capítulo da admissibilidade ${ }^{49}$, o juízo deve analisar se os pressupostos processuais estão preenchidos e, esse ponto é autônomo em relação ao pleito da jurisdição, com a antecedência de análise e subordinação. Não haverá julgamento de mérito sem a análise positiva da admissibilidade, em capítulo autônomo e, evidentemente, que essa análise pode culminar numa admissibilidade negativa.

No tocante à divisão interna do próprio mérito, o processo pode ser complexo objetivamente $^{50}$ pela existência de diversas relações jurídicas, seja pela cumulação de diversos pedidos na mesma demanda, seja pela inclusão de uma pluralidade de autores ou de réus - ou de ambos, tornando uma demanda múltipla em pedidos ou em relações jurídicas a serem resolvidas.

Diante disso, no mérito, cada capítulo será autônomo a outros capítulos, um pedido será julgado com autonomia a outro pedido, cada relação jurídica entre as partes será julgada com autonomia em relação a outra relação, com exceção ao litisconsórcio unitário ${ }^{51}$.

Se todos os capítulos do processo podem ser julgados de modo autônomo, em todas as situações pode ocorrer uma cisão cognitiva e fracionamento decisório, separando

47 DINAMARCO, Cândido Rangel. Capítulos de sentença. $3^{\text {a }}$. ed. São Paulo: Malheiros, 2008. p. 42.

48 "o tipo de sentença que importa para os fins desse trabalho é aquele em que coexiste mais de uma resolução de mérito.” BARBOSA MOREIRA, José Carlos. Sentença Objetivamente Complexa, Trânsito em Julgado e Rescindibilidade. Revista Dialética de Direito Processual. Vol. 45, São Paulo: Dialética, dez/2006. p. 54

49 "o exame da admissibilidade do procedimento nada mais é do que o exame da possibilidade de o objeto litigioso ser apreciado." DIDIER JR., Fredie. Curso de direito processual civil: teoria geral do processo e processo de conhecimento. 17ª ed. Salvador: Juspodivm, 2015. p. 445.

50 Sobre a nomenclatura: BARBOSA MOREIRA, José Carlos. Sentença Objetivamente Complexa, Trânsito em Julgado e Rescindibilidade. Revista Dialética de Direito Processual. Vol. 45, São Paulo: Dialética, dez/2006. p. 54.

51 Por este ser considerado como somente uma "pessoa" em juízo, para fins processuais e relacionais, apesar da pluralidade. 
Rio de Janeiro. Ano 15. Volume 22. Número 3. Setembro a Dezembro de 2021

Periódico Quadrimestral da Pós-Graduação Stricto Sensu em Direito Processual da UERJ

Patrono: José Carlos Barbosa Moreira (in mem.). ISSN 1982-7636. pp. 1067-1124

www.redp.uerj.br

capítulos para serem julgados em decisão parcial e com outros aguardando para uma decisão somente no ato da sentença? A resposta é negativa, mesmo diante de um processo complexo objetivamente, o que determina a possibilidade de cisão será a relação do processo, dos seus capítulos decisórios autônomos com as questões de fato, seja do próprio processo, seja de situações específicas, como fatos atinentes a um pressuposto processual específico.

No entanto, pertinente entender que as questões de fato não perfazem capítulos do processo, somente trabalham diante de uma cognição judicial necessária para definição da narrativa fática $^{52}$ a ser considerada como um suporte fático concreto para a resolução dos capítulos.

Logo, na existência de um processo objetivamente complexo, com cumulação de pedidos ou pluralidade de partes, a cognição judicial estará envolta a resolver questões de fato $^{53}$ que serão a base para a definição das questões de direito e, consequentemente, do julgamento de cada capítulo do processo e, em algumas hipóteses, possibilitar que esse julgamento seja cindido cognitivamente, com a resolução dos capítulos em momentos diversos do processo, fracionamento os momentos decisórios existentes.

A cisão de um processo somente será possível se tivermos um processo objetivamente complexo, o que seria o primeiro requisito para a possibilidade que o juízo possa perceber a possibilidade de prolatar uma decisão parcial, com o prosseguimento da instrução do capítulo - ou capítulos - restante.

Mesmo diante das espécies de decisão parcial - com ou sem resolução do mérito, o processo ser objetivamente complexo é a base para essa específica pluralidade cognitiva e, diante disso, a abertura para uma cisão e fracionamento decisório.

Por outro lado, se um processo não detém essa complexidade objetiva, igualmente não é cindível. Essa pluralidade e complexidade que possibilita a cisão cognitiva e o

52 DIDIER JR., Fredie. Objeto da cognição judicial. Revista Dialética de Direito Processual. Vol. 6, p. 12 23, São Paulo: Dialética, set/2003. p. 15.

53 "Há questões de fato, correspondentes à dúvida quanto a uma assertiva de fato contida nas razões de alguma das partes." DINAMARCO, Cândido Rangel. O conceito de mérito em processo civil. Revista de Processo. Vol. 34, Ano 9, p. 20-46, São Paulo: Ed. RT, Abril/Jun/1984. p. 25. 
Rio de Janeiro. Ano 15. Volume 22. Número 3. Setembro a Dezembro de 2021

Periódico Quadrimestral da Pós-Graduação Stricto Sensu em Direito Processual da UERJ

Patrono: José Carlos Barbosa Moreira (in mem.). ISSN 1982-7636. pp. 1067-1124

www.redp.uerj.br

fracionamento decisório, afinal, somente pode ser cindido aquilo que é plural ${ }^{54}$, aquilo que é passível de divisão ${ }^{55}$.

Ultrapassada a necessidade da complexidade objetiva do processo para que seja possível a cisão, passa-se à análise do segundo requisito: a pluralidade de questões de fato a serem resolvidas. Se houver pluralidade de questões de fato, diante de um processo complexo objetivamente, abre-se a possibilidade, diante da interligação das questões e dos pedidos e partes, para que se possa cindir a cognição, com a prolação, se cumpridos critérios de resolução e incontrovérsia parcial fática ${ }^{56}$, de uma decisão parcial da demanda.

Depois desse requisito, um ponto fundamental para possibilitar que o juízo prolate uma decisão parcial é a estabilização ou resolubilidade de ao menos uma das questões de fato.

Desse modo, se for viável que o juízo resolva determinada questão de fato, seja por já ser passível de resolução ${ }^{57}$, seja pelo reconhecimento das partes sobre da questão de fato base para determinado pedido, tornando-se incontroversa ${ }^{58}$.

54 Sobre a necessidade de pluralidade e divisibilidade: “Obviamente, apenas pode-se cogitar de resolução parcial do mérito quando comportar ele próprio, o meritum causae, divisão." SIQUEIRA, Thiago Ferreira. O julgamento antecipado parcial do mérito no Novo Código de Processo Civil brasileiro. Civil Procedure Review. Vol. 7, p. 165-208, 2016. p. 182.

55 "Assim, é possível a ocorrência de desmembramento na apreciação (acolhimento, rejeição, extinção parcial do processo) dos pedidos durante o andamento da relação processual, fazendo com que, o processo passe a tratar apenas de pedido simples ou a diminuição dos pedidos cumulados. Eventualmente, esse desmembramento poderá ensejar decisão definitiva, inclusive, com cognição suficiente para ensejar a imunização do julgado.” ARAÚJO, José Henrique Mouta. A resolução parcial de mérito e a coisa julgada progressiva: reflexos no sistema processual como forma de assegurar a brevidade da prestação jurisdicional. Belém, PA, 2004. 302 p. Tese (Doutorado). Universidade Federal do Pará. Programa de Pós-Graduação em Direito. p. 145.

56 Sobre a possibilidade dessa incontrovérsia fática ser de modo tácito: "Será, por exemplo, a hipótese do réu que, contestando, repelisse as consequências jurídicas pretendidas pelo autor, sem infirmar a verdade dos fatos por ele arguidos, mas sem acolhê-los, expressamente, como verdadeiros. (...) A questão será puramente de direito, exigindo, de logo, o seu julgamento." CALMON DE PASSOS, José Joaquim. Comentários ao código de processo civil. Vol. III, $6^{\text {a }}$ ed. Rio de Janeiro: Forense, 1989. p. 422.

57 “As questões de fato são resolvidas mediante prova; a prova, portanto, é um argumento de certificação para que o juiz possa ter como verdadeira ou procedente determinada argumentação fática." MACÊDO, Lucas Buril. Coisa julgada sobre fato? análise comparativa com o collateral estoppel de sua possibilidade de lege lata ou de lege ferenda. Revista de Processo. vol. 260, p. 355 - 412, São Paulo: Ed. RT, Out / 2016. p. 363.

58 Se um determinado fato é relevante para a demanda, com potencial de ser uma questão de fato pertinente à solução de um dos pedidos - ou vários pedidos - e o réu concorda com a narrativa do autor, há uma incontrovérsia fática, tornando resolvida aquela outrora potencial questão de fato: "Diz-se que no processo existe questão simplesmente de direito quando não há controvérsia relativa ao fato. Autor e réu admitem a presença, no caso, de determinado fato. Estão de acordo quanto ao modo de ser desse fato." MACHADO, Hugo de Brito. As questões de fato e a sentença de mérito. Revista Dialética de Direito Processual. Vol. 96, p. 65-71, São Paulo, mar/2011. p. 68. 
Rio de Janeiro. Ano 15. Volume 22. Número 3. Setembro a Dezembro de 2021

Periódico Quadrimestral da Pós-Graduação Stricto Sensu em Direito Processual da UERJ

Patrono: José Carlos Barbosa Moreira (in mem.). ISSN 1982-7636. pp. 1067-1124

www.redp.uerj.br

Em qualquer dessas hipóteses, a questão de fato é o ponto de partida - junto com a complexidade objetiva do processo - para a quebra cognitiva do processo, é o momento em que abre-se a possibilidade para a cindibilidade, dada a configuração de uma bifurcação cognitiva existente pela resolubilidade ou estabilização da questão de fato ${ }^{59}$ autorizante ou pela incontrovérsia desta ${ }^{60}$ - e vinculada a um pedido ou uma cognição específica.

Obviamente que a estabilização dessa questão de fato específica tornando-a incontroversa ou a abertura para a sua resolubilidade devem relacionar-se com a possibilidade de julgamento de parcela específica do processo, utilizando como base somente esse ponto fático resolúvel cognitivamente, sem a necessidade de que prossiga, uma vez que não depende de outras questões de fato serem resolvidas.

O que pode ser julgado de modo a cindir o processo deve depender somente dessa questão de fato específica e, com a configuração da viabilidade dessa resolução, consequentemente, abre-se a possibilidade de cindir o processo.

Entretanto, há mais um requisito, a necessidade de que a outra parcela do processo - os demais pedidos - ainda necessitem de, no mínimo, outra questão de fato ainda pendente, com a exigência de uma instrução probatória para tanto.

Logo, são requisitos, para a cisão cognitiva, a existência de uma pluralidade de questões de fato a serem resolvidas ${ }^{61}$, e, após a resolução e estabilização de, no mínimo, uma determinada questão de fato, que esta autorize o julgamento de parcela de demanda, com outras questões de fato - ou ao menos uma - continuando pendentes, proporcionando o prosseguimento do restante do processo - os demais pedidos, dada a pendência fática para sua cognição total.

59 Para que uma questão de fato seja resolvível antecipadamente, as provas devem estar ali dispostas para tanto, sem necessidade de novas produções de provas: "A solução de uma questão de fato depende, evidentemente, da prova que seja oferecida pelas partes." MACHADO, Hugo de Brito. As questões de fato e a sentença de mérito. Revista Dialética de Direito Processual. Vol. 96, p. 65-71, São Paulo, mar/2011. p. 69.

60 Sobre a incontrovérsia dos fatos: “a incontrovérsia dos fatos pode ser expressa ou tática. Deriva, a tácita, do comparecimento e da contestação do réu, que silencie sobre os fatos postos pelo autor." GRINOVER, Ada Pellegrini. O julgamento antecipado da lide: enfoque constitucional. Revista de Processo. Vol. 5, Ano 2, p. 101-114, São Paulo: Ed. RT, Jan/Mar/1977. p. 106.

61 "Diante de um fato controvertido, o primeiro cuidado do julgador deve ser examinar sua pertinência; subsequentemente, relevância, se acaso admitido como pertinente; por último, a pertinência e a relevância, não mais do fato em si mesmo, sim da prova que sobre esse fato a parte pretende produzir." CALMON DE PASSOS, José Joaquim. Comentários ao código de processo civil. Vol. III, $6^{\text {a }}$ ed. Rio de Janeiro: Forense, 1989. p. 423/424. 
Rio de Janeiro. Ano 15. Volume 22. Número 3. Setembro a Dezembro de 2021

Periódico Quadrimestral da Pós-Graduação Stricto Sensu em Direito Processual da UERJ

Patrono: José Carlos Barbosa Moreira (in mem.). ISSN 1982-7636. pp. 1067-1124

www.redp.uerj.br

Ou seja, como requisitos para uma cisão cognitiva, há a seguinte construção necessária: (i) a complexidade objetiva do processo por cumulação de pedidos ou pluralidade de partes; (ii) a pluralidade de questões de fato; (iii) a resolubilidade ou estabilização via incontrovérsia de uma questão de fato e pendência de, no mínimo, outra questão de fato; (iv) a dependência de parcela da demanda somente da questão de fato já resolvida/estabilizada.

Por mais que o ordenamento processual não mencione nada sobre a relação da questão de fato e a possibilidade da prolação de decisões parciais e cisões cognitivas, evidentemente que a questão de fato resolvida - ou em estado cognitivo para tanto - é uma das bases possibilitantes para a resolução parcial de um processo que for complexo objetivamente e houver pluralidade de questões de fato, resolvendo um capítulo e postergando os demais para uma prolação de sentença após a resolução de outras questões de fato outrora pendentes.

Se todas as questões de fato necessitarem ${ }^{62}$ de instrução probatória para resolver a demanda, ainda que complexa objetivamente, não há viabilidade de cisão cognitiva, por resolver-se tudo ao mesmo tempo, ou seja, na prolação da sentença.

De igual maneira, se uma questão de fato contiver resolubilidade desde logo na procedimentalidade, mas não for totalmente influenciante a algum pedido, com todos os pleitos necessitando da resolução de outras questões, igualmente deve-se aguardar tais resoluções para a prolação da sentença, posteriormente, decidindo toda a complexidade do processo ao mesmo tempo.

Ou seja, diante dessas questões, é importante delinear que a resolução de questão de fato é um dos requisitos para a cindibilidade do processo complexo objetivamente, diante dos requisitos expostos, porém outros desdobramentos sobre a questão de fato devem ser configurados para que seja possível a cisão cognitiva e o fracionamento decisório, tais

62 Sobre questão de fato, para que seja necessário o seu deslinde e a produção de prova deve ser, além de contraditória nas narrativas fáticas, pertinentes e relevantes, como ensina Calmon de Passos: "Existindo fatos controvertidos, a necessidade de prova a respeito deles exige, ainda, que esses fatos controvertidos sejam pertinentes e relevantes. Fato pertinente é o que diz respeito à causa, o que não lhe é estranho. Fato relevante, aquele que, sendo pertinente, é também capaz de influir na decisão da causa." CALMON DE PASSOS, José Joaquim. Comentários ao código de processo civil. Vol. III, $6^{\text {a }}$ ed. Rio de Janeiro: Forense, 1989. p. 428. Por outro lado, sobre a possível impertinência do fato: "Fato impertinente é o que não diz respeito à causa, por ser-lhe estranho." GRINOVER, Ada Pellegrini. O julgamento antecipado da lide: enfoque constitucional. Revista de Processo. Vol. 5, Ano 2, p. 101-114, São Paulo: Ed. RT, Jan/Mar/1977. p. 107. 
Rio de Janeiro. Ano 15. Volume 22. Número 3. Setembro a Dezembro de 2021

Periódico Quadrimestral da Pós-Graduação Stricto Sensu em Direito Processual da UERJ

Patrono: José Carlos Barbosa Moreira (in mem.). ISSN 1982-7636. pp. 1067-1124

www.redp.uerj.br

como: (i) a pluralidade de questões de fato; (ii) a relação específica dessa questão de fato com um dos pedidos; (iii) a pendência de outras questões de fato para outro pedido.

Após esse ponto é importante analisar a interligação das questões de fato com a possibilidade das decisões parciais sem e com mérito.

\subsection{As questões de fato para a cognição da decisão parcial sem mérito}

A extinção da demanda é uma possibilidade decisória consequente da análise sobre preenchimento pelo autor ${ }^{63}$ dos pressupostos processuais inerentes ao próprio ato de postular e o resultado pela constatação de alguma irregularidade. Se o processo não cumprir algum dos pressupostos de existência ${ }^{64}$ ou de validade ${ }^{65}$, consequentemente, não terá a admissibilidade para que prossiga em sua procedimentalidade, bem como não alcançará o julgamento de mérito.

Inicialmente, uma vez constatada a existência de um vício no processo, é salutar que o juízo analise se este é sanável e oportunize que ao autor o prazo para corrigir o vício $^{66}$, para o devido prosseguimento da demanda, com diversos dispositivos nesse sentido. Se for sanável, com prazo para sanabilidade concedido e não for realizada tal feito, o processo deve ser extinto ${ }^{67}$, bem como se o vício for diretamente insanável, partindo logo

63 Ou do réu em eventual reconvenção.

64 Sobre o termo "pressuposto de existência": CARVALHO, José Orlando Rocha de. Teoria dos pressupostos e dos requisitos processuais. Rio de Janeiro: Lumen Juris, 2005.

65 Sobre a validade, a acepção correta seriam requisitos de validade e não pressupostos: "Costuma-se falar em pressupostos de existência e de validade. A terminologia merece uma correção técnica. Pressuposto é aquilo que precede ao ato e se coloca como elemento indispensável para a sua existência jurídica; requisito é tudo quanto integra a estrutura do ato e diz respeito à sua validade (...). Assim, é mais técnico falar em requisitos de validade, em yez de "pressupostos de validade"." DIDIER JR., Fredie. Curso de direito processual civil: teoria geral do processo e processo de conhecimento. $17^{\mathrm{a}}$. ed. Salvador: Juspodivm, 2015. p. 315.

66 Sobre a sanabilidade do vício na demanda e a necessidade de oportunizar ao autor prazo devido para tanto, impossibilitando o juízo de prolatar uma decisão automática de extinção: "São vícios que o maculam. Se puderem ser sanados, o juiz deverá ordenar neste sentido, cabendo providenciar a parte, em prazo não superior a trinta (30) dias." LIMA, Alcides Mendonça de. As providências preliminares no código de processo civil brasileiro de 1973. Revista de Processo. Vol. 1, Ano 1, p. 26-42, São Paulo: Ed. RT, 1976. p. 39. No CPC/2015: "a regra é a de que se deve aplicar, ao exame dos pressupostos processuais, o sistema de invalidades do CPC, segundo o qual se deve buscar, sempre, a correção do defeito processual, mesmo que se trate da falta de um pressuposto processual. Remetemos o leitor aos capítulos sobre as normas fundamentais do processo civil (princípio da primazia da decisão de mérito) e invalidades processuais." DIDIER JR., Fredie. Curso de direito processual civil: teoria geral do processo e processo de conhecimento. 17ª ed. Salvador: Juspodivm, 2015. p. 315.

67 Sobre a extinção do processo por vício insanável: “Assim, fazendo presente aquilo que prevê o art. 317 deve o juiz, antes de proferir decisão sem resolução do mérito, que não é o objetivo do processo, deve 
Rio de Janeiro. Ano 15. Volume 22. Número 3. Setembro a Dezembro de 2021

Periódico Quadrimestral da Pós-Graduação Stricto Sensu em Direito Processual da UERJ

Patrono: José Carlos Barbosa Moreira (in mem.). ISSN 1982-7636. pp. 1067-1124

www.redp.uerj.br

para sua extinção ${ }^{68}$, uma vez que seria impossível de conceder prazo para sanar o que não tem sanabilidade.

Para que seja possível a prolação de uma decisão parcial sem resolução de mérito, igualmente deve preencher os requisitos delineados e mencionados no subcapítulo anterior sobre a necessidade de complexidade objetiva da demanda, pluralidade de questões de fato e resolubilidade parcial destas questões, bem como a pendência de resolução de uma questão com impacto na parcela que prosseguirá em litispendência.

A complexidade objetiva da demanda continua sendo necessária para a cisão cognitiva do processo, mesmo que esta seja para julgar parcela sem exame de mérito, com base no art. 354, parágrafo único do CPC. Há, portanto, a necessidade de que haja uma pluralidade de partes em um dos polos da demanda ou que se tenha uma cumulação de pedidos para que seja possível a prolação de uma decisão parcial sem resolução do mérito $^{69}$.

Se houver pluralidade de partes em um dos polos - ou de ambos - do processo, é possível analisar os pressupostos sobre cada relação jurídica existente entre autor x réu, de

oportunizar à parte a faculdade de corrigir o noticiado vício, desde que sanável, por óbvio." THAMAY, Rennan Faria Kruger. Manual de direito processual civil. São Paulo: Saraiva, 2018. p. 254. Esse cuidado para que haja a possibilidade de sanabilidade seria uma das manifestações do dever de prevenção do juízo: MARINONI, Luiz Guilherme; ARENHART, Sérgio Cruz; MITIDIERO, Daniel. Novo código de processo civil comentado. São Paulo: Ed. RT, 2015. p. 331.

68 Sobre a insanabilidade do vício e a necessidade de prolação de decisão sem mérito: "Se, porém, a matéria tiver de ser decidida a favor do réu, acolhendo uma ou alguma de suas alegações (como o reconhecimento de coisa julgada ou de carência de ação), ou se houver nulidade insanável, o juiz deverá proferir sentença, extinguindo o processo (...) Ocorrerá um caso do julgamento conforme o estado do processo, embora sem decidir o mérito.” LIMA, Alcides Mendonça de. As providências preliminares no código de processo civil brasileiro de 1973. Revista de Processo. Vol. 1, Ano 1, p. 26-42, São Paulo: Ed. RT, 1976. p. 39. No CPC/2015: “extingue o processo em função de outro pressuposto processual, como a capacidade da parte, a inépcia da petição inicial, a litispendência, a coisa julgada ou, simplesmente, porquanto a ação se exauriu, como no caso da sentença que extingue a execução." TESHEINER, José Maria Rosa; THAMAY, Rennan Faria Kruger. Teoria Geral do Processo: em conformidade com o Novo CPC. Rio de Janeiro: Forense, 2015. p. 173.

69 Sobre essa decisão parcial sem mérito como possível no ordenamento processual anterior: "E, sendo um, pode sofrer extinção quanto à parte apenas do seu objeto, ou só com respeito a um ou alguns dos litisconsorciados, quando inadmitida, ou separadamente julgada no seu mérito, uma só ou só algumas das ações que nele se processam; ou ainda quando se verifique alguma das situações definidas no art. 267 que só afete a uma ou algumas das ações submetidas a simultaneus processus. Essa é a situação que propomos denominar extinção "imprópria"e do processo e que, como a verdadeira extinção, pode-se dar com ou sem julgamento do mérito. Dizemo-la imprópria porque a denominação não se ajusta ao conteúdo conceitual, nem se compatibiliza, do ponto de vista semântico, com a continuação do processo que aí ocorre. Extinção contém a idéia de encerramento, término, ponto final. E, no caso, tal não se dá, pois o processo deve prosseguir sua marcha. Trata-se, pois, de extinção impropriamente dita - ou, mais simplesmente, extinção imprópria.” FABRÍCIO, Adroaldo Furtado. Ensaios de direito processual. Rio de Janeiro: Forense, 2003. p. 237. 
Rio de Janeiro. Ano 15. Volume 22. Número 3. Setembro a Dezembro de 2021

Periódico Quadrimestral da Pós-Graduação Stricto Sensu em Direito Processual da UERJ

Patrono: José Carlos Barbosa Moreira (in mem.). ISSN 1982-7636. pp. 1067-1124

www.redp.uerj.br

cada autor com cada réu, com a possibilidade de exclusão de quem não for legitimado para estar em juízo, com a continuidade das relações que forem legítimas para aquela relação jurídica e aquele processo.

Desse modo, somente é excluído quem não detiver legitimidade para estar em juízo, tanto ativa quanto passivamente, com a prolação de uma decisão parcial sem resolução do mérito.

Se houver cumulação de pedidos, os pressupostos processuais são isolados a cada pedido, com a devida análise se a demanda individual de cada pedido cumulado é possível e cumpriu os requisitos atinentes a cada um destes.

Como os pressupostos processuais devem ser preenchidos de modo individualizado para cada um dos pedidos, se um pedido não tiver esse preenchimento e os demais sim, de modo positivo, é possível a prolação da decisão parcial sem resolução do mérito, com a extinção parcial do processo $^{70}$ sobre aquele pedido que não cumpriu os pressupostos processuais a ele inerentes.

Mas, existirá uma relação dessa decisão parcial sem resolução do mérito com as questões de fato? A resposta é positiva, afinal toda a análise sobre o preenchimento ou não dos pressupostos processuais será diante de um suporte fático concreto sobre a admissibilidade do processo, com total influência das questões de fato sobre a cognição judicial das preliminares de conhecimento do processo.

Igualmente as questões de fato devem ser plurais para a possibilidade de uma cisão cognitiva do processo sem mérito, com a resolução de uma questão específica sobre o ponto do processo que será extinto. Todavia é importante diferenciar as questões de fato sobre a própria demanda e determinado pedido das questões de fato sobre a admissibilidade desse mesmo pedido.

Um exemplo seria a existência de uma cláusula compromissória de arbitragem para o objeto de um pedido, mas que não alcança o outro pedido do processo, a análise desse pressuposto processual negativo será no limite do pedido impactado. A existência, ou não, dessa cláusula é uma questão de fato que culminará na resolução de uma questão de direito

70 Câmara critica esse termo "extinção parcial": "Veja-se que neste caso não há uma "extinção parcial do processo" (ideia absolutamente equivocada, absurda mesmo, já que nada pode ser "parcialmente extinto"). O que há nessas hipóteses é a redução subjetiva ou objetiva do processo, por decisão interlocutória, impugnável por agravo de instrumento (art. 354, parágrafo único)." CÂMARA, Alexandre Freitas. O novo processo civil brasileiro. $4^{\text {a }}$ ed. São Paulo: Atlas, 2018. p. 201. 
Rio de Janeiro. Ano 15. Volume 22. Número 3. Setembro a Dezembro de 2021

Periódico Quadrimestral da Pós-Graduação Stricto Sensu em Direito Processual da UERJ

Patrono: José Carlos Barbosa Moreira (in mem.). ISSN 1982-7636. pp. 1067-1124

www.redp.uerj.br

que impedirá o prosseguimento desse pedido na jurisdição estatal, com a prolação de uma decisão parcial sem resolução do mérito para esse pedido, mas que possibilita o prosseguimento do restante do processo, referente ao pedido não impactado pela referida cláusula.

Logo, sobre o preenchimento dos pressupostos processuais podem ser analisadas as questões de fato narradas pelo autor para toda a demanda e processo, bem como outros fatos específicos de cada pressuposto, diante de ocorrências e alegações do réu na demanda e processo, ou do próprio juízo no que puder conhecer de ofício, como na existência de coisa julgada de somente um dos pedidos, por exemplo.

Sobre a legitimidade e interesse de agir, a análise poderá ser perfunctória, baseada já na narrativa dos fatos pelo próprio autor ${ }^{71}$, uma vez que a extinção parcial impactará somente ele. Se o autor narrar os fatos e não demonstrar que é legítimo ou que tenha interesse processual para determinado pedido, o juízo pode pedir esclarecimentos e sanabilidade e, se for o caso, julgar extinto o processo para aquela parte. Se houver uma pluralidade de partes, se for um litisconsórcio, somente deve ser excluído este litisconsorte, seja por ilegitimidade, seja por falta de interesse deste em relação aos pedidos.

Nessa situação, a própria narrativa do autor ${ }^{72}$ pode servir como base para essa análise já na inicial, contudo pode também ser somente em momento posterior, com alegações sobre esses pontos pelo réu, na peça de defesa, com análise posterior, no saneamento, por exemplo, extinguindo parcialmente a demanda, com a exclusão daquele determinado litisconsorte que não for legítimo ou o pedido que não for demonstrado interesse processual existente.

De qualquer modo, há a necessidade da resolução cognitiva de uma questão de fato que possibilite a extinção somente de parcela da demanda. No entanto, é pertinente o entendimento de que esta questão de fato autorizante da prolação de uma decisão parcial

71 Seria a base da teoria da asserção: "O que importa é a afirmação do autor, e não a correspondência entre a afirmação e a realidade, que já seria problema de mérito.” MARINONI, Luiz Guilherme. Novas linhas do processo civil. 3• ed. São Paulo: Malheiros, 1999. p. 212.

72 Explicando a teoria da asserção: "A aferição das "condições da ação" se faz através de uma técnica conhecida como teoria da asserção. Não obstante este nome, de uso consagrado, não se está aí diante de uma verdadeira teoria, mas de uma técnica para verificação da presença das "condições da ação". Asserção, como cediço, significa afirmação, e daí vem o nome desta técnica, por força da qual as "condições da ação" devem ser examinadas in statu assertionis, isto é, no estado das afirmações feitas pela parte em sua petição.” CÂMARA, Alexandre Freitas. O novo processo civil brasileiro. $4^{\mathrm{a}}$ ed. São Paulo: Atlas, 2018. p. 36. 
sem mérito não é necessariamente uma questão de fato sobre a matéria de fundo, mas uma alegação de fato sobre o preenchimento ou não dos pressupostos processuais inerentes a própria formação da relação processual.

\subsection{As questões de fato para a cognição da decisão parcial com mérito: uma classificação}

Para que seja possível uma decisão parcial de mérito são necessários vários requisitos preenchidos, como exposto, contudo é importante delinear como requisito também a existência de uma pluralidade de questões de fato e, ainda, que haja uma interligação entre essas questões de fato e a complexidade objetiva da demanda, com a concepção sobre uma independência total entre as questões de fato, com a uma total possibilidade de cindir o processo e julgar parcialmente ou uma independência parcial, autorizando, de igual maneira, a cisão cognitiva, mas com algumas diferenças.

Para tanto, há a necessidade de classificar essas situações entre as impossibilidades de cisões por causa da ausência de independência fática e as possibilidades entre independência total e parcial.

3.2.1 Impossibilidade de cisão de mérito: processo com total dependência entre a resolução das questões de fato e os pedidos ou relações jurídicas entre as partes

Apesar do enfrentamento de questões de fato em um processo objetivamente complexo, é pertinente lembrar que num processo simples também pode conter diversas questões de fatos a serem resolvidas, todas insertas na causa de pedir e influenciantes às questões de direito e ao pedido constante no pleito de jurisdição.

No entanto, aos processos simples objetivamente, apesar da possibilidade de diversas questões de fato, não há a possibilidade de cisão cognitiva por estarem envoltos diante de uma matéria de fundo somente, dada a unicidade do pedido e da relação entre um autor e um réu.

Diante disso e numa comparação com os processos complexos objetivamente, são três situações sobre questões de fato que se tem como descartáveis para este estudo, pela 
Rio de Janeiro. Ano 15. Volume 22. Número 3. Setembro a Dezembro de 2021

Periódico Quadrimestral da Pós-Graduação Stricto Sensu em Direito Processual da UERJ

Patrono: José Carlos Barbosa Moreira (in mem.). ISSN 1982-7636. pp. 1067-1124

www.redp.uerj.br

inadequação à situação que enfrentada, dada a impossibilidade de cisão de mérito, justamente relação sua relação com as questões de fato, as quais são listadas da seguinte maneira: (i) pluralidade de questões de fato, um só pedido e somente uma parte em cada polo; (ii) pluralidade de pedidos ou partes em algum dos polos, contudo com somente uma questão de fato; (iii) pluralidade de pedidos ou de partes em um dos polos, com questões de fato que forem entrelaçadas, com a resolução de todos os pedidos ou relações do processo dependendo de todas as questões de fato.

Quando houver pluralidade de questões de fato e um só pedido, com somente uma parte em cada polo será impossível a cisão cognitiva de mérito e fracionamento decisório pelos motivos a serem enfrentados.

Nessa situação, a primeira impossibilidade de cisão cognitiva no mérito passa pela existência de somente um pedido, o que por si só já impede ou dificulta tal cisão, tornando esse processo simples objetivamente.

A segunda impossibilidade fundamenta-se, por mais que as questões de fato sejam múltiplas, no fato do pedido depender da resolução de todas as questões de fato para que seja possível ser julgado, o que impede que essa multiplicidade proporcione uma grande cisão ou complexidade processual nos impactos de cada questão de fato resolvida.

A ligação do pedido único no processo com múltiplas questões de fato impede que a resolução de somente uma questão de fato autorize a decisão sobre o pedido, dada a pendência de outras questões de fato para tal desiderato decisório.

Essa questão de fato com resolubilidade ou incontrovérsia pode gerar uma decisão interlocutória e não ser resolvida somente na sentença? Esse ponto é interessante e importante, mas seria uma espécie diferente de fracionamento decisório, sem ser uma decisão sobre o mérito, sobre o pedido e a jurisdição em si, mas a resolução de uma questão de fato, sem enquadrar-se em uma decisão parcial.

Então, se o processo não pode ser fracionado por conter somente um pedido, importaria a quantidade de questões fáticas? Se as partes forem somente uma em cada um dos polos, a princípio a resposta tenderia a ser negativa. Todavia, é possível que o pedido seja decomponível ${ }^{73}$, com a interligação de uma questão de fato para a procedência do

73 “quando a pretensão incide sobre bens sujeitos a alguma espécie de quantificação, seja por unidades (dinheiro, coisas fungíveis em geral), por peso, volume etc. A decomponibilidade do objeto do processo significa que o juiz pode conceder ao autor toda a quantidade que ele pediu, ou nada, ou parte dessa 
Rio de Janeiro. Ano 15. Volume 22. Número 3. Setembro a Dezembro de 2021

Periódico Quadrimestral da Pós-Graduação Stricto Sensu em Direito Processual da UERJ

Patrono: José Carlos Barbosa Moreira (in mem.). ISSN 1982-7636. pp. 1067-1124

www.redp.uerj.br

pedido e a outra para a decomposição ${ }^{74}$. Ou seja, se há a possibilidade de que a procedência do pedido seja possível, justamente pela resolubilidade da questão de fato que a constitui, contudo ainda haja a necessidade de instrução sobre outra questão de fato essencial para a quantificação da condenação outrora julgada.

Mas, será que um pedido decomponível não seria visto como uma pluralidade de pedidos? Essa é outra questão pertinente.

Fora dessas hipóteses de decomposição do pedido, essa pluralidade de questões de fato e um só pedido não trará grande complexidade para a cognição, justamente pelo processo não ser objetivamente complexo nestas configurações processuais.

Nesse caso, pelo pedido ser somente um, mesmo que a quantidade de questões de fato seja plural, esta diversidade somente multiplica a cognição sobre tais pontos fáticos, sem complicações de interligações com diversos pedidos ou partes e, consequentemente, sem a possibilidade de prolação de uma decisão parcial de mérito, sem a cindibilidade do processo.

Ou seja, essa eventual complexidade na cognição sobre as questões de fato descreve que todas são atinentes a um só pedido, impedindo a cisão cognitiva de mérito, tampouco fracionamento decisório, com toda a solução judicial a ser prolatada tendo o momento da sentença como o correto a ser decidido.

Um exemplo seria a discussão sobre um pedido de indenização sobre danos materiais por causa de um acidente de trânsito. O pedido seria somente a condenação para o pagamento de danos pelo prejuízo material, contudo pode se ter questões de fato diversas, como a própria existência do acidente (apesar de improvável alegação pelo réu), o modo como o acidente ocorreu e, ainda, a existência ou não de dano a ser reparado. Todas as possíveis questões de fato são inerentes a subsidiar o pedido de dano material, o que importa de uma pluralidade de questões de fato para fundamentar um só pedido, o que impede a cisão, como explanado.

quantidade.” DINAMARCO, Cândido Rangel. A reforma da reforma. $3^{a}$. ed. São Paulo: Malheiros, 2002. p. 101.

74 Sobre a decomposição de objeto único: "São várias as situações que conduzem a divisão de uma sentença em dois ou mais capítulos de mérito, cada um dos quais decidindo sobre um desses objetos autônomos. Agrupam-se essas situações em dois blocos distintos, (a) um dos quais é apresentado pelo cúmulo de pretensões de algum modo deduzidas em um só processo e (b) o outro decorre de uma abstração condizente na decomposição do objeto único." DINAMARCO, Cândido Rangel. Capítulos de sentença. $3^{\text {a }}$. ed. São Paulo: Malheiros, 2008. p. 64. 
Quando houver pluralidade de pedidos ou partes em algum dos polos, contudo com somente uma questão de fato influenciando todos os pedidos ou relações jurídicas entre as partes, a resolução desta questão impacta o processo como um todo, com a exigência de aguardo desta questão para que todos os pedidos sejam julgados.

Por mais que o processo seja objetivamente complexo, se há somente um fato a ser resolvido - o que deve certo modo é excepcional ${ }^{75}$ - e se tem dois ou mais pedidos cumulados ou pluralidade em algum dos polos, tem-se a interligação entre a resolução da questão de fato com o próprio desenrolar das questões de mérito e do próprio mérito do processo como um todo, por ser somente uma controvérsia fática que concederá o suporte concreto para a decisão em sua integralidade, de todos os pedidos ou de todas as relações jurídicas entre as diferentes partes, possibilitando o juízo a julgar toda a matéria com somente uma cognição fática, prolatando somente um ato decisório - a sentença.

Nesse ínterim, natural que a decisão sobre a pluralidade de pedidos ou das relações jurídicas entre as partes ocorrerá em momento conjunto, na prolação de sentença, sem tanta complexidade cognitiva sobre questão de fato, uma vez que ao resolver essa questão de fato ainda aberta em controvérsia, todos os pedidos cumulados e relações jurídicas estarão aptas a serem julgadas, sem permitir qualquer cisão de mérito na cognição, sem permitir qualquer decisão parcial, até pela desnecessidade desta pela iminência da prolação de uma sentença que encerre todo o procedimento.

Mesmo que haja a incontrovérsia ou resolubilidade antecipada sobre essa questão de fato e a possibilidade de julgamento antecipado, todos os pedidos poderão ser julgados antecipadamente, o que também impossibilidade uma cisão cognitiva por causa dessa única questão de fato a ser resolvida no processo.

Quando houver pluralidade de pedidos ou de partes em um dos polos, com questões de fato que forem entrelaçadas, com a resolução de todos os pedidos ou relações do processo dependendo de todas as questões de fato serem resolvidas também será inviável a cisão cognitiva de mérito.

75 Já exemplificado anteriormente essa hipótese quando houver uma ação com pedido de inexistência de débito e obrigação de fazer para retirar o nome do cadastro de inadimplentes. Dois pedidos e uma só questão de fato base para o deslinde da situação processual. 
Nessa situação, os pedidos cumulados - ou relações jurídicas entre a pluralidade de partes - dependem das mesmas questões de fato serem resolvidas, sem conter nenhuma independência entre a resolução das questões de fato e o restante da matéria da demanda.

Por todas as matérias de fundo do processo serem impactadas pelas mesmas questões de fato, quando estas forem resolvidas, o processo como um todo já poderá ser julgado, com a autorização e conclusão para a prolação de uma só decisão, ou seja, o julgamento de toda a matéria na sentença, sem a possibilidade de cisão cognitiva, uma vez que por mais que haja cumulação de pedidos ou pluralidade de partes, a interligação de ambos às mesmas questões de fato autoriza o julgamento dos pedidos somente quando todas essas questões forem resolvidas e, quando forem, apesar dos pedidos ou relações serem independentes materialmente entre si, são dependentes da resolução das mesmas questões de fato.

Essa hipótese traz consigo um processo objetivamente complexo, mas somente isso não autoriza a cisão cognitiva, uma vez que a complexidade de interligações das questões de fatos com toda a matéria do processo impedem esse fracionamento decisório, dada a existência de diversas questões de fato, porém com todas influenciando todos os pontos materiais do processo, culminando, quando resolvidos os fatos, na prolação da sentença, com a resolução integral do processo.

Se todos os pedidos ou relações entre as partes dependem das mesmas questões de fato, não há independência fática para a prolação de uma decisão parcial de mérito, com a necessidade de que toda a matéria do processo fique apta ao mesmo tempo para a prolação da sentença, uma vez que dependem da cognição judicial sobre os mesmos fatos, ainda que estes sejam plurais. Quando estes forem resolvidos, toda a matéria poderá ser enfrentada, resolvida e julgada na prolação da sentença, sem cisão cognitiva, até por sua desnecessidade diante dessa situação específica.

Todas essas hipóteses acima explanadas e explicadas entram na categoria de impossibilidade de cisão cognitiva de mérito pela conjunção da questão de fato e cumulação de pedidos ou pluralidade das partes, pelos motivos expostos.

\subsubsection{A possibilidade de cisão de mérito pela independência fática}


Rio de Janeiro. Ano 15. Volume 22. Número 3. Setembro a Dezembro de 2021

Periódico Quadrimestral da Pós-Graduação Stricto Sensu em Direito Processual da UERJ

Patrono: José Carlos Barbosa Moreira (in mem.). ISSN 1982-7636. pp. 1067-1124

www.redp.uerj.br

A cisão cognitiva do processo que permite uma decisão parcial de mérito tem como requisito inicial ser objetivamente complexo ${ }^{76}$, seja pela cumulação de pedidos, seja pela pluralidade de partes e, ainda, a possibilidade de julgar um dos pedidos no transcorrer do procedimento $^{77}$ e postergar os demais pedidos para a prolação da sentença.

Além da complexidade objetiva do processo, essa hipótese necessita de todos os outros requisitos mencionados, como a conjunção da pluralidade de questões de fato, a resolubilidade ou estabilização de uma questão de fato e pendência de, no mínimo, outra questão de fato e a dependência ${ }^{78}$ de parcela do processo somente da questão de fato já resolúvel ou estabilizada.

Ou seja, as questões de fato, a resolubilidade de uma delas e seu grau de influência nos pedidos é determinante para que seja possível a prolação da decisão parcial de mérito, nos moldes do art. 356 do CPC.

Nessas hipóteses, a questão de fato não possibilita por si só a cisão cognitiva do processo, sem ser a autorização única da prolação de decisão parcial de mérito, mas a questão de fato e sua resolubilidade ou estabilização demonstram que o modo, quantidade e o impacto desta são importantes para a possibilidade, ou não, da prolação de uma decisão parcial de mérito.

Numa situação hipotética como essa, a interligação entre questões de fato com os pedidos deve ser considerada para a devida classificação e entendimento sobre as diferenças entre as situações processuais e, dessa maneira, com a configuração de uma situação autorizante do fracionamento decisório no processo.

Para tanto, importante delinear os graus de interligação entre as questões de fato e os pedidos para que se saiba as espécies dessa relação, o que pode-se construir uma

76 BARBOSA MOREIRA, José Carlos. Sentença objetivamente complexa, trânsito em julgado e rescindibilidade. Revista Dialética de Direito Processual. Vol. 45, São Paulo: Dialética, dez/2006. p. 54.

77 "Em caso de acumulação de demandas, na qual apenas um pedido (correspondente a uma demanda) foi julgado, sem que se tenha examinado o outro, parece existir omissão total, porquanto na verdade eram duas as demandas a serem julgadas por uma única sentença, esta dividida substancialmente em capítulos." OLIVEIRA, Vallisney de Souza. Nulidade da sentença e o princípio da congruência. São Paulo: Saraiva, 2004. p. 270.

78 Dinamarco explica a independência dos capítulos de sentença no tocante aos seus objetos, o que propomos o trabalho aqui é a visão de que essa independência material dos pedidos e capítulos não enseja, automaticamente, uma independência fática, o que importa em entendermos que a questão de fato - ou ponto fático - deve ser analisado para que possa ser possível, ou não, uma cisão cognitiva entre os capítulos de sentença. DINAMARCO, Cândido Rangel. Capítulos de sentença. $3^{a}$. ed. São Paulo: Malheiros, 2008. p. 43. 
Rio de Janeiro. Ano 15. Volume 22. Número 3. Setembro a Dezembro de 2021

Periódico Quadrimestral da Pós-Graduação Stricto Sensu em Direito Processual da UERJ

Patrono: José Carlos Barbosa Moreira (in mem.). ISSN 1982-7636. pp. 1067-1124

www.redp.uerj.br

classificação como: (i) pluralidade de questões de fato e interligação específica de cada pedido com um fato; (ii) pluralidade de questões de fato, com uma destas com impacto em ambos os pedidos e uma outra questão de fato que impacta somente um dos pedidos.

Diante dessa classificação acima mencionada, é pertinente o enfrentamento de cada uma dessas hipóteses em que a resolução de questão de fato autoriza no processo objetivamente complexo a cisão cognitiva e um fracionamento decisório, com a possibilidade de prolação de uma decisão parcial de mérito.

\subsubsection{Independência fática total}

A cisão cognitiva será possível se um processo contiver uma pluralidade de pedidos ou de partes em um dos polos e uma pluralidade de questões de fato - exemplo, duas questões de fato e dois pedidos cumulados ou pluralidade de partes em um dos polos.

Se um processo tem duas questões de fatos e dois pedidos diferentes, com cada questão de fato relacionada a um só pedido, estes guardam, faticamente, independência entre si. Dessa maneira, a resolubilidade de cada questão de fato impacta somente ao pedido específico a ela relacionada, sem qualquer impacto no outro pedido, o que importa em não existir nenhuma interligação entre as questões de fato.

Numa hipótese como essa, não há relação entre as questões de fato e na interligação entre essas questões e as de direito, cada relação é estanque, criando duas relações questão de fato/questão de direito - totalmente e igualmente estanques no processo. Cada resolubilidade de fato possibilita a cognição e decisão de uma questão de direito que será fundamento para um pedido, podendo, portanto, a partir da resolução da questão de fato passar-se ao julgamento daquela parcela do processo.

Desse modo, há total independência entre as cumulações, justamente pelas questões de fato não serem interligadas entre si, o que importa, dessa feita, numa situação em que resolvendo uma questão de fato, somente um pedido é impactado, sem qualquer influência no outro pedido.

Se uma questão de fato for resolúvel ou resolvida de modo precoce, sem a resolução da outra questão de fato existente, aquele pedido que tem interligação específica com a questão de fato já resolúvel ou resolvida, deve ser julgado em decisão parcial de 
Rio de Janeiro. Ano 15. Volume 22. Número 3. Setembro a Dezembro de 2021

Periódico Quadrimestral da Pós-Graduação Stricto Sensu em Direito Processual da UERJ

Patrono: José Carlos Barbosa Moreira (in mem.). ISSN 1982-7636. pp. 1067-1124 www.redp.uerj.br

mérito, com o prosseguimento do processo para a instrução probatória da questão de fato ainda pendente de resolução e, consequentemente, com o pedido da parcela restante do processo aguardando o desenrolar dessa instrução probatória.

Um exemplo seria uma cumulação de pedidos sobre a ocorrência de um acidente de trânsito, com o pedido de danos materiais pelo prejuízo no veículo e danos materiais por gastos hospitalares. Sem controvérsia sobre como o acidente ocorreu, as questões de fato seriam sobre a existência de cada dano - uma questão de fato sobre o prejuízo no veículo e outra sobre os gastos hospitalares. Se houver incontrovérsia sobre os danos materiais no veículo, mas ainda há controvérsia se existem gastos hospitalares ou se estes são relacionados com o acidente, o juízo pode, desde logo, cindir o processo com a prolação de uma decisão parcial de mérito sobre o pedido de dano material pelo prejuízo no veículo, justamente pela relação questão de fato e pedido, neste caso, ser estanque, sem a questão de fato do prejuízo pelo dano no veículo impactar o do hospital e vice-versa.

Essa hipótese melhor é visualizável quando a cumulação for de pedidos que não compartilhem a mesma causa de pedir ${ }^{79}$, tornando as questões de fato sobre cada ponto totalmente diversas e, consequentemente, independentes. Todavia, mesmo que seja em pedidos da mesma causa de pedir, é possível a mesma autonomia, justamente se contiver a ocorrência de fatos estanques entre si na sua relação com os pedidos.

Uma vez configurada tal situação inter-relacional entre fatos e direito, é possível a decisão parcial de mérito pela total independência entre os capítulos do processo, seja no direito, seja nos fatos.

Essa hipótese pode ser definida como uma cumulação de pedidos com autonomia entre os capítulos decisórios e independência fática.

\subsubsection{Independência fática parcial}

Outra hipótese é um processo que contém duas - ou mais - questões de fato e pedidos cumulados, com uma questão comum a todos os pedidos, com um pedido

79 Sobre pedidos cumulados com causa de pedir diversas na mesma ação, seria uma mesma ação cobrando, por exemplo, dois contratos diversos entre o mesmo autor e réu, cada pedido relacionado com cada contrato, o que geraria uma independência de causas de pedir e pedidos e, consequentemente, as questões de fato também serem estanques e, dessa maneira, totalmente viável a cisão do processo com a prolação de uma decisão parcial, caso configurável a resolubilidade de parcela do processo. 
dependente somente desta uma questão de fato e os outros pedidos com a necessidade da definição de outra questão de fato. Seriam duas questões de fatos e dois pedidos, uma questão de fato é comum aos dois pedidos e uma questão de fato é somente a um dos pedidos.

Nesse caso, se resolvida a questão de fato comum a todos os pedidos, para aquele pedido que somente depende dessa resolução fática, abre-se a possibilidade da prolação da decisão parcial de mérito, pela existência da independência desse pedido pela questão de fato que lhe é atinente já ser resolvida, mesmo que esta questão também influencie os demais pedidos.

Esse pedido não depende de qualquer outra questão de fato, podendo, então, ser julgada desde logo, sem a necessidade de instrução probatória.

O outro pedido que ainda depende da resolução da outra questão de fato aguardará a instrução probatória, porém utilizará o que se decidiu sobre a questão de fato resolvida e decidida na decisão parcial de mérito com o acréscimo da resolução da questão de fato que ainda necessitava de resolução, numa junção da questão de fato decidida na decisão parcial e essa questão a ser enfrentada somente na sentença para se definir o suporte fático para esse pedido a ser julgado na sentença.

Obviamente que essa situação não é de fácil percepção e depende de muito cuidado na análise do juízo e das partes. O processo já é complexo objetivamente e contém uma pluralidade de questões de fato, contudo a configuração da situação processual é autorizante em potencial da cisão cognitiva por um dos pedidos depender da resolução de somente uma questão de fato, independentemente desta também influenciar um outro pedido que dependerá desta questão e de outra, ainda pendente de resolução, com a necessidade de instrução probatória.

Logo, a questão de fato já resolúvel ou resolvida é impactante a todos os pedidos, mas por conter subsídios para a cognição em relação à sua resolução e esta impactar um dos pedidos com a possibilidade de uma cognição exauriente, essa situação e enquadramento de bifurcação processual permite haja uma cisão cognitiva para julgar o pedido que depender somente desta questão, fracionando a decisão do processo em dois momentos - um via interlocutório e um na sentença. 
Todavia, essa resolução da questão de fato na decisão parcial de mérito impactará o outro pedido, dada uma independência fática somente de modo parcial. O complexo dessa hipótese é a recorribilidade dessa decisão parcial que define o fato comum a todos os pedidos, uma vez que o agravo de instrumento impugnativo dessa decisão parcial de mérito pode versar sobre a definiçãa da questão de fato, com pedido de reexame de provas e análise dos fatos e um eventual êxito recursal pode impactar essa resolução fática para este pedido julgado na decisão parcial e os demais.

Mesmo com a prolação da decisão parcial de mérito, há uma continuidade da interligação entre os pedidos - o já julgado e o que ainda depende da resolução de outras questões de fato.

Essa hipótese pode ser definida como uma cumulação de pedidos com autonomia entre os capítulos decisórios e independência fática parcial, somente sobre uma das questões.

Um exemplo dessa situação seria uma ação de danos morais e materiais pelo cancelamento - ou overbooking - de um voo por uma companhia aérea. O cancelamento pode ser uma questão de fato, se controvertido, que influencia tanto os danos morais quanto os materiais, contudo com a resolubilidade pela existência do cancelamento, os danos morais podem ser julgados - em casos in re ipsa - sem nenhum outro desdobramento fático, contudo os danos morais necessitariam de uma questão de fato, a comprovação do prejuízo material, mas o cancelamento também é base para seu suporte fático. Uma vez que se julga pela existência do cancelamento e o julgamento de danos morais, essa definição fática serve para a decisão parcial, com a possibilidade de cisão e fracionamento do processo, bem como será suporte fático para a prolação da sentença posteriormente, sobre os danos materiais.

\subsection{O impacto da classificação de independência total e independência parcial nas espécies de cumulação}


Rio de Janeiro. Ano 15. Volume 22. Número 3. Setembro a Dezembro de 2021

Periódico Quadrimestral da Pós-Graduação Stricto Sensu em Direito Processual da UERJ

Patrono: José Carlos Barbosa Moreira (in mem.). ISSN 1982-7636. pp. 1067-1124

www.redp.uerj.br

Diante do preenchimento de requisitos ${ }^{80}$ e da classificação entre impossibilidade de cisão por dependência das questões de fato e possibilidade de cisão por independência, com esta última se dividindo entre independência total e parcial, é importante delinear a relação dessas possibilidades com cada espécie de cumulação de pedidos.

As cumulações se dividem entre objetiva (pedidos) e subjetiva (litisconsórcio), com subdivisão interna a estes, as quais serão discriminados para uma melhor classificação.

Sobre as cumulações de pedidos, estas são a base inicial para possibilitar que o processo seja objetivamente complexo e, posteriormente, se cumprir os demais requisitos delineados, seja possível a cisão cognitiva. As cumulações são divididas entre: simples, sucessiva, eventual/subsidiária e alternativa.

As possibilidades relacionais entre cumulação de pedidos e questões de fato podem ocorrer nas seguintes situações: (i) pluralidade de pedidos e unidade de questão de fato; (ii) pluralidade de pedidos e pluralidade de questões de fato, com interligação de todas as questões a todos os pedidos; (iii) pluralidade de pedidos e pluralidade de questão de fato, com interligação específica de pedido/questão de fato; (iv) pluralidade de pedidos e pluralidade de questão de fato, com um fato específico de um pedido e outro fato comum a todos os pedidos.

Na cumulação simples, o intuito do autor é que todos os pedidos sejam julgados, com a cumulação de pedidos para a própria economicidade processual e a harmonia das decisões de matérias comuns, se houver a conexão da causa de pedir.

Essa cumulação proporciona uma divisão autônoma do processo em capítulos e independência em termos materiais, uma vez que o julgamento de um dos pedidos não condiciona o resultado do outro pedido, tampouco o seu julgamento.

No entanto, deve-se diferenciar essa independência existente na cumulação de pedidos sobre a matéria de cada um dos pedidos e a independência em termos fáticos, sobre as questões de fato. Essa total independência entre os pedidos significa que não importa o resultado de um pedido para que se julgue o outro, tampouco um resultado

80 Essa classificação proposta sobre a possibilidade de cisão cognitiva com fracionamento decisório do processo tem como base os requisitos apresentados como necessários para essa cindibilidade, os quais são: (i) a complexidade objetiva do processo por cumulação de pedidos ou pluralidade de partes; (ii) a pluralidade de questões de fato; (iii) a resolubilidade ou estabilização via incontrovérsia de uma questão de fato e pendência de, no mínimo, outra questão de fato; (iv) a dependência de parcela da demanda somente da questão de fato já resolvidalestabilizada. 
condiciona o resultado do outro, podendo um pedido ser procedente e outro improcedente, com ambos sendo julgados, uma vez que não há relação de subordinação, tampouco hierarquia entre estes.

Todavia, essa independência material não é sinônimo da independência sobre a questão de fato diante da construção dos requisitos apresentados neste trabalho, sendo esta construção inerente à autorização, ou não, da possibilidade de cindir a cognição via uma série de requisitos entre processo objetivamente complexo e resolubilidade das questões de fato.

Como a cumulação simples é a mais aberta de todas, como a regra do que seria a cumulação, com a independência entre pedidos, no tocante às questões de fato seguirão a construção proposta, ou seja, quando houver cumulação de pedidos, mas com questões de fato - uma ou várias - que são atinentes, ao mesmo tempo, a todos os pedidos, não deterão independência fática e deverão ser julgados ao mesmo tempo, no momento da prolação da sentença.

De outro modo, se houver alguma questão de fato que seja específica de um pedido simples $^{81}$, sem atinência ao outro pedido, com a resolubilidade ou resolução dessa questão de modo anterior às outras questões de fato, o processo com cumulação de pedidos simples pode ser cindido, dada a independência material e fática.

$\mathrm{Na}$ cumulação sucessiva de pedidos, o intuito do autor é realizar dois pedidos, contudo com a sucessividade de análise.

Desse modo, apesar de existente dois - ou mais pedidos, um deles é antecedente e condicionante ao outro, com a necessidade de que haja a procedência - ou parcial procedência - do primeiro para que se possa conhecer desse segundo, com ulterior decisão.

Nessa situação, há primeiro a concentração cognitiva em relação ao julgamento do primeiro pedido e somente após a procedência desse pedido, cognitivamente, passa-se de mera possibilidade de julgar-se o segundo pedido para a realidade de iniciar o julgamento.

De outro modo, se o primeiro pedido for improcedente, o segundo sequer é julgado.

81 Essa é a hipótese mais fácil de exemplificação, com a cumulação de pedidos de danos morais e materiais, com questões de fato diversas entre si, o que resulta na possibilidade de julgar parcialmente se uma das questões de fato se tornar incontroversa ou com resolubilidade antecipada. Por outro lado, se ambas dependerem de uma mesma questão de fato, somente será possível na sentença, como já exemplificado em momento anterior, uma ação de inexistência de débito e obrigação de fazer para retirar o nome do cadastro de inadimplentes, ambos os pedidos dependem da mesma questão de fato. 
Não há uma independência entre as matérias e pedidos cumulados, justamente pela própria subordinação e hierarquia existente. Mas, sobre a questão de fato, a independência trabalha no mesmo plano? Evidentemente que não, dependendo, igualmente à cumulação simples, sobre como funcionará a interligação entre as questões de fato e os pedidos realizados.

No entanto, cumpre diferenciar as espécies de cumulação sucessiva: a cumulação sucessiva do procedimento comum; e a cumulação sucessiva dos procedimentos especiais.

É importante essa diferenciação pelo fato de que a cumulação sucessiva do procedimento comum possibilita que a sentença a ser prolatada possa conter, ao mesmo tempo, a resolução do pedido condicionante e do pedido condicionado.

Pela cumulação ser sucessiva, no procedimento comum, somente há uma subordinação e hierarquia nessa sucessividade, com a necessidade de análise primeiro de determinado pedido condicionante e, em caso de procedência, passa-se à cognição das questões envoltas ao segundo pedido, com a possibilidade de julgamento deste, o qual pode ser na mesma sentença, se for possível em termos das questões de fato inerentes a este segundo pedido.

Se todos as questões de fato forem resolvidas sobre o segundo pedido, na procedência do primeiro, a mesma sentença já pode iniciar o julgamento do subsequente.

Nessa cumulação sucessiva, se a dependência dos dois pedidos existentes forem sobre a mesma questão de fato, ao julgar o primeiro pedido procedente, na sentença já inicia-se o julgamento seguinte. Igualmente ocorre quando forem duas questões de fato que impactam ambos os pedidos, com a necessidade de que ambas sejam resolvidas para possibilitar o primeiro julgamento e, assim, novamente se for procedente, passa-se ao seguinte.

Nessas duas hipóteses, os pedidos têm interligação e dependência das mesmas questões de fato.

No entanto, se nessa sucessividade, houver questão de fato independente para o pedido condicionante, com pendência fática para o segundo, o juízo prolata a decisão somente sobre o primeiro pedido, a qual terá duas hipóteses de espécie de decisão: $(i)$ se for procedente será uma decisão parcial de mérito; (ii) e se for improcedente, já será uma sentença, pela desnecessidade de julgar o pedido posterior/sucessivo. 
Na procedência da decisão parcial de mérito, nesse caso, abre-se o procedimento para a resolução da questão de fato pendente para o julgamento do segundo pedido, aquele que somente foi possível a abertura cognitiva pela procedência do primeiro.

O mesmo ocorrerá quando os pedidos sucessivos tiverem uma pluralidade de questão de fato, contudo com a resolução de uma questão de fato comum a ambos, porém que esta possibilite o julgamento do pedido condicionante, autorizando, portanto, a prolação da decisão parcial de mérito, se for procedente, ou sentença, se for pela improcedência.

De igual maneira, se for uma decisão parcial de mérito pela procedência ${ }^{82}$, abrir-seá um procedimento para a resolução da questão de fato inerente ao segundo pedido, aquele condicionado.

Já na cumulação sucessiva dos procedimentos especiais, a cisão cognitiva é inerente à própria procedimentalidade imaginada pelo legislador, com a diferença específica entre os procedimentos, com o primeiro pedido contendo uma procedimentalidade até o seu julgamento, que pode ser uma decisão parcial de mérito, se for julgada procedente - ou parcialmente - e pode ser uma sentença, se julgada improcedente.

O legislador entendeu que, nas hipóteses desses pedidos sucessivos em procedimentos especiais ${ }^{83}$, os procedimentos são diferentes, com um específico para chegar à primeira decisão e, na hipótese de procedência desta, inaugura-se um novo procedimento rumo a alcançar uma nova decisão.

A cisão cognitiva nos procedimentos especiais especificados no ordenamento é obrigatória $^{84}$ em resultado de procedência, sem a possibilidade de julgar todos os pedidos

82 Calmon de Passos exemplifica situações em que há cumulação sucessiva: "É o que ocorre na cumulação do pedido de reconhecimento da paternidade com o de petição de herança: sem que seja tornada certa a filiação, impossível se apreciar o direito à sucessão. Mas a relação entre os pedidos pode ser de principal para acessório, como a acumulação dos pedidos de pagamento do principal e dos juros, da reintegração na posse e da condenação em perdas e danos etc.” CALMON DE PASSOS, José Joaquim. Comentários ao código de processo civil. Vol. III, 6 ${ }^{a}$ ed. Rio de Janeiro: Forense, 1989. p. 203.

83 A regra é diferente nos procedimentos especiais bipartidos, por não ser uma demanda que nasce para ser una e biparte-se, mas, ao inverso: "verificam-se algumas previsões expressas de julgamentos parciais também no âmbito de determinados procedimentos especiais que se podem denominar bifásicos ou bipartidos, como se demonstra a seguir." CORREIA FILHO, Antonio Carlos Nachif. Julgamentos parciais no processo civil. São Paulo, SP, 2015. 176 p. Dissertação (Mestrado). Universidade de São Paulo. Programa de Pós-Graduação em Direito. p. 80.

84 Essa obrigatoriedade não nasce somente da vontade do legislador em transformar um procedimento em especial, mas pela própria lógica daquela tutela a ser proferida. A própria natureza do direito que se discute tem esse formato, com a especialidade como uma tutela diferenciada necessária. "Atentos 
Rio de Janeiro. Ano 15. Volume 22. Número 3. Setembro a Dezembro de 2021

Periódico Quadrimestral da Pós-Graduação Stricto Sensu em Direito Processual da UERJ

Patrono: José Carlos Barbosa Moreira (in mem.). ISSN 1982-7636. pp. 1067-1124

www.redp.uerj.br

em uma só sentença. Ou o primeiro pedido é improcedente e, desse modo, não possibilita a continuidade do processo, sem julgar o segundo pedido, por ser sucessivo, ou julga-se procedente o primeiro pedido em uma decisão necessariamente parcial de mérito, com a abertura da procedimentalidade para discutir-se a cognição do segundo pedido.

Ou seja, a decisão parcial de mérito é inserta de alguns procedimentos especiais como sua procedimentalidade base, como na ação de exigir contas, divisão e demarcação de terras e consignação em pagamento com dúvida sobre o credor. O próprio legislador percebe que há uma independência das matérias e de questões de fato e, ainda, uma sucessividade, com dois procedimentos diversos, com o segundo somente existindo na procedência do primeiro pedido.

As duas outras cumulações serão impróprias, com o pleito pelo julgamento de um pedido específico, mas com subsidiariedade ou alternatividade a este. A cumulação existente de modo impróprio não trabalha com a intenção de que todos os pedidos sejam julgados, mas com o pleito por um julgamento, uma só jurisdição a ser prestada, porém com a possibilidade de outros julgamentos, seja de modo subsidiário, seja de modo alternativo.

Na cumulação subsidiária ou eventual, a apreciação de um segundo pedido está condicionada a ser analisada somente se o primeiro pedido não for julgado procedente, conforme a dicção do art. 326 do CPC. Os pedidos serão listados de modo subsidiário, com uma ordem de preferência para a análise do juízo formulada pelo autor, com a possibilidade de conhecimento do pedido posterior quando o juízo não acolher o anterior.

respeitando tais premissas não podemos nem devemos esquecer que outros requisitos não existem simplesmente pela vontade do legislador, mas porque atende exigências cientificamente postas ou a serem postas, por serem corolários de verdades, normalmente encontradas nos rincões do direito material." ROCHA, José de Moura. Sobre os procedimentos especiais. Revista de Processo. Vol. 53, Ano 14, p. 22-30, São Paulo: Ed. RT, jan/mar/1989. p. 26. No CPC/2015: “Além do procedimento comum, o Código prevê vários procedimentos especiais contenciosos, cuja estrutura básica é a mesma do procedimento comum, mas adaptada ritualmente às necessidades específicas da tutela reclamada por determinadas relações ou situações de direito material. É o que se passa, por exemplo, com as ações de família, os juízos divisórios e demarcatórios, a sucessão causa mortis, as consignações em pagamento, as prestações de conta e várias outras demandas, cujo acertamento não se comportaria, adequadamente, dentro do procedimento comum." THEODORO JR., Humberto. Curso de direito processual civil. Vol. I, 59ª ed. Rio de Janeiro: Forense, 2018. p. 779. 
É o inverso da cumulação sucessiva. Há uma prejudicialidade85 entre os pedidos, sem a possibilidade de que todos sejam analisados concomitantemente, pelo fato de que o autor pleiteou uma só jurisdição e deu opções para o exercício desta, com a diferença de que na subsidiária optou por posicionar as opções em uma ordem de preferência.

O importante para o autor, na cumulação subsidiária, é o julgamento do primeiro pedido listado, na ordem de preferência. Se esse pedido for julgado procedente, não há que se falar em julgar outros pedidos ${ }^{86}$, contudo se o resultado for pela improcedência, procede-se a abertura cognitiva para julgar o próximo pedido.

Mas, há uma influência da questão de fato sobre essa cumulação e a possibilidade, ou não, de prolação de decisão parcial de mérito? Essa indagação é pertinente.

Sobre a independência sobre as questões de fato, se houver unidade de questão de fato sobre os pedidos, o primeiro na ordem e o subsidiário, na hipótese de julgamento improcedente do primeiro, na mesma sentença o juízo já decide o segundo, sem a possibilidade de cisão cognitiva. Da mesma forma ocorrerá se houver pluralidade de questões de fato, com interligação de todas as questões a ambos pedidos.

Entretanto, se houver uma pluralidade de questões de fato, contudo com uma questão que possibilita o pedido condicionante, já será possível a prolação da decisão sobre este pedido. Se for pela procedência, será prolatada em sentença, sem necessidade de julgar nenhum outro pedido. Caso contrário, se for pela improcedência, seria uma decisão parcial de mérito, com a abertura cognitiva para julgar o segundo pedido, contudo este segundo pedido necessitaria de uma instrução probatória própria, dada a pendência de uma questão de fato para ser resolvida para esse julgamento subsidiário.

De igual maneira, será possível a decisão parcial em cumulação subsidiária se houver pluralidade de questão de fato, com um fato comum aos dois pedidos já resolvido condicionante e subsidiário - e, quando o primeiro for julgado improcedente, ainda há um

85 “os pedidos não se situam no mesmo plano, mas um deles é formulado como principal e outro, só na eventualidade de não ser possível acolher o principal.” CALMON DE PASSOS, José Joaquim. Comentários ao código de processo civil. Vol. III, 6a ed. Rio de Janeiro: Forense, 1989. p. 204.

86 Um exemplo seria num contrato de compra e venda de um automóvel, com a constatação de defeito no automóvel, com a ação pleiteando de modo preferencial a devolução com a restituição dos valores e, caso improcedente, que seja determinada a obrigação de fazer de reparos no automóvel. Como ambos os pedidos dependem da questão de fato sobre a existência ou não do defeito, ambos somente seriam viáveis de serem julgados na sentença, contudo com a necessidade da análise do primeiro pedido e, se improcedente, o do pedido posterior. Todavia, se para o segundo pedido houver uma questão de fato específica, há a possibilidade da prolação da improcedência do primeiro pedido em decisão parcial e o restante com a postergação para a sentença. 
Rio de Janeiro. Ano 15. Volume 22. Número 3. Setembro a Dezembro de 2021

Periódico Quadrimestral da Pós-Graduação Stricto Sensu em Direito Processual da UERJ

Patrono: José Carlos Barbosa Moreira (in mem.). ISSN 1982-7636. pp. 1067-1124

www.redp.uerj.br

fato específico para que se julgue esse pedido subsidiário ${ }^{87}$, o que ensejaria a cisão numa decisão parcial de mérito pela improcedência do primeiro pedido e a abertura para a instrução probatória para a resolução da questão de fato que possibilitará julgar o segundo pedido, agora na sentença.

$\mathrm{Na}$ cumulação alternativa, o autor formula mais de um pedido no processo, contudo de modo alternativo ${ }^{88}$, com a liberdade para que o juízo acolha qualquer deles, em conformidade com o art. 326, parágrafo único do CPC ou pela natureza da obrigação, o devedor puder cumprir a prestação de mais de um modo, no art. 325 do CPC.

Sobre a primeira hipótese, apesar de dois ou mais pedidos existentes, o intuito é a apreciação de somente um, o que nem seria uma cumulação autêntica de pedidos, mas uma cumulação de ações que podem ser totalmente diferentes entre $\mathrm{si}^{89}$. Para o autor, a procedência de somente um dos pedidos já lhe basta, sem o intento de querer a análise de todos, tampouco a procedência de todos, sem nenhuma hierarquia de apreciação, tampouco subordinação entre os pedidos realizados pelo autor, somente a possibilidade aberta para que a procedência satisfativa seja de modo alternativo.

O julgamento pela procedência de um dos pedidos já encerra a prestação jurisdicional, o que possibilita entender que se um dos pedidos for pela procedência, independe a questão de fato sobre os demais pedidos, uma vez que sequer serão analisados, dada a impossibilidade escolhida pelo próprio autor ao realizar tal espécie de cumulação.

Contudo, caso haja a improcedência de um pedido, não gera o encerramento da jurisdição, com a necessidade de que se analise o outro pedido, o que pode importar em uma cisão cognitiva pela improcedência, via decisão parcial de mérito, e a necessidade de prosseguimento sobre as outras questões de fato para poder julgar o pedido alternativo que restou.

87 Não se pode é julgar primeiro o pedido subsidiário, numa inversão da ordem de preferência estipulada pelo autor: “'É fundamental que as cumulações, sendo o caso, respeitem a relação existente entre as pretensões cumuladas, de modo a que aquela subordinada ao êxito da outra não se decida em primeiro lugar por sentença parcial.” ARMELIN, Donaldo. Notas sobre sentença parcial e arbitragem. Revista de Arbitragem e Mediação. n. 18, v. 5, São Paulo: Ed. RT, jul/set/2008. p. 274.

88 Alguns não consideram como uma cumulação, tanto que nem a colocam nessa categoria: ASSIS, Araken de. Cumulação de ações. 4a. ed. São Paulo: Ed. RT, 2002. p. 242.

89 O mesmo exemplo da compra e venda de automóvel cabe para este pedido cumulado de modo alternativo, somente que o autor tenha pleiteado de modo alternativo, sem uma ordem sequencial, com o mesmo contexto sobre a improcedência de um ou outro e a decisão parcial de mérito, no caso com a necessidade de seja improcedente. 
Rio de Janeiro. Ano 15. Volume 22. Número 3. Setembro a Dezembro de 2021

Periódico Quadrimestral da Pós-Graduação Stricto Sensu em Direito Processual da UERJ

Patrono: José Carlos Barbosa Moreira (in mem.). ISSN 1982-7636. pp. 1067-1124

www.redp.uerj.br

Todavia, isso somente será possível diante de uma questão de fato ser comum a todos os pedidos, podendo, portanto, já enfrentá-los todos em uma sentença, por causa da improcedência de um dos pedidos e o julgamento do outro. Mas, se a questão de fato for independente entre os pedidos, com a improcedência ${ }^{90}$ pode gerar uma decisão parcial de mérito e a cisão cognitiva, com a abertura da busca pela resolubilidade da questão de fato inerente ao pedido não julgado ainda.

$\mathrm{Na}$ segunda hipótese de cumulação alternativa, quando a obrigação puder ser cumprida de modo alternativo, o pedido é somente um, mas o cumprimento é possível em modo à escolha do réu, o que deve ser mencionado por este na contestação ou no cumprimento de eventual sentença, não em divisão na condenação que possibilite uma cisão cognitiva.

Na cumulação subjetiva, o que existe é uma pluralidade de partes no polo ativo, passivo ou em ambos. Essa cumulação aumenta a subjetividade em torno da relação jurídica da demanda, com a inclusão de mais de uma parte presente no polo ativo ou passivo. Mesmo que haja somente um pedido, o fato de haver um litisconsórcio, desde que não seja unitário ${ }^{91}$, a relação jurídica se torna plúrima ${ }^{92}$, com esse pedido se multiplicando entre cada polo e suas quantidades.

90 "Entretanto, é possível imaginar a prolação de decisão parcial de improcedência de um dos pedidos alternativos (v.g., autor pleiteia o cumprimento da obrigação mediante pagamento de quantia em dinheiro ou mediante a cessão de quotas hereditárias de pessoas vivas). Neste caso, eliminar-se-ia um dos bens da vida (pedido mediato) visados pelo autor, prosseguindo o processo para o exame de seu direito à obtenção do bem da vida restante. Todavia, como a procedência de qualquer dos pedidos alternativos satisfaz integralmente a pretensão (que é única) do demandante, verifica-se que os honorários advocatícios somente deverão ser fixados ao final do processo, tendo em vista que, neste momento, não seria possível a aferição da sucumbência." OLIVEIRA FILHO, Silas Dias de. Julgamento fracionado do mérito e implicações no sistema recursal. São Paulo, SP, 2013. 256 p. Dissertação (Mestrado). Universidade de São Paulo. Programa de Pós-Graduação em Direito. p. 113; "não se enxerga óbice a que o juiz rejeite um dos pedidos inclusive na cumulação imprópria alternativa, quando note, por exemplo, que a entrega do bem comprado seja impossível, restando apenas a análise quanto ao direito de devolução do preço e seus termos." BARBOSA, Bruno Valentim. Julgamentos parciais de mérito no processo civil individual brasileiro. São Paulo, SP, 2013. 161 p. Dissertação (Mestrado). Universidade de São Paulo. Programa de Pós-Graduação em Direito. p. 29.

91 A diferença está no litisconsórcio unitário, aquele que a decisão de mérito atinge todos as partes de igual maneira, sem conter lides cindidas. A sentença prolatada será somente uma, como nas demais, mas sem a possibilidade de cisão em capítulos, mesmo com pluralidade de partes, pelo fato de que o pedido continua sendo somente um, mesmo produzindo eficácia a diversos atores, contudo é o mesmo efeito para todos unitariamente. Sobre litisconsórcio unitário: THAMAY, Rennan Faria Kruger. Manual de direito processual civil. São Paulo: Saraiva, 2018. p. 178/179.

92 "do ponto de vista substancial, a presença de várias pessoas, na qualidade de autores ou de réus, sugere um número correspondente de ações.” ASSIS, Araken de. Cumulação de ações. 4ª ed. São Paulo: Ed. RT, 2002. p. 140. 
A cumulação subjetiva ou litisconsórcio tem o condão de trazer consequências de caráter objetivo ao processo $^{93}$, primeiramente por tornar o objeto litigioso do processo complexo e proporciona a divisão da própria lide e sua cognição dividida em capítulos, com diferentes pedidos e impactos perante cada autor e cada réu litisconsorte, dependendo da relação existente entre cada ator processual.

Nessa cumulação subjetiva há uma pluralidade de relações jurídicas entre os polos, com diversos pedidos diante da subjetividade das relações internas no processo, com a mesma questão sobre a questão de fato e a possibilidade, ou não, de cisão cognitiva dos pedidos.

Se o processo girar em torno da relação entre essa pluralidade de partes e unidade de questão de fato, a sentença será o momento de decidir todas as relações, julgando o pedido existente, sem possibilidade de cisão cognitiva, pela questão de fato ser una. Igualmente será se houver pluralidade de partes e pluralidade de questões de fato, com interligação de todas as questões a todos os pedidos, ocorrendo o mesmo, com a sentença resolvendo todas as questões e relações.

No entanto, se houver pluralidade de partes, sem ser litisconsórcio unitário, e pluralidade de questão de fato, com interligação específica de cada questão de fato com a relação de cada parte - autor-réu ${ }^{94}$, se resolvida uma questão determinada, resolve-se via decisão parcial de mérito as relações possíveis, com a continuidade do processo em busca da resolução da questão de fato para resolver a relação que ainda está pendente, na sentença.

De igual maneira, quando houver pluralidade de partes e pluralidade de questão de fato $^{95}$, com um fato específico de uma relação autor-réu e outro fato comum a todos as

93 "pedir a condenação de dois a pagar é pedir uma sentença que, em capítulos autônomos, condene um e condene outro; e o juiz poderá condenar ambos, ou não condenar nenhum ou condenar só um deles e o outro não." DINAMARCO, Cândido Rangel. Capítulos de sentença. 3a. ed. São Paulo: Malheiros, 2008. p. 69.

94 "Em todos os referidos exemplos parece existir um traço comum: o litisconsórcio induziu ao alargamento do objeto litigioso. A presença de plúrimas partes no polo ativo ou passivo, ampliando o esquema mínimo da demanda (do ponto de vista do elemento subjetivo), deu ensejo a um acúmulo de pedidos, nas suas mais variadas modalidades, com a consequência (i) de tornar complexo o objeto litigioso e (ii) de impor a segmentação da resposta jurisdicional, no mais das vezes, em múltiplos capítulos de mérito." AMBRIZZI, Tiago Ravazzi. Julgamento fracionado do mérito no processo civil brasileiro. São Paulo, SP, 2014. 231 p. Dissertação (Mestrado). Universidade de São Paulo. Programa de Pós-Graduação em Direito. p. 141.

95 Existem diversos exemplos possíveis, desde um litisconsórcio em que o autor inseriu duas partes no polo passivo de uma só indenização e a necessidade de julgar cada uma delas em relação ao dever de 
Rio de Janeiro. Ano 15. Volume 22. Número 3. Setembro a Dezembro de 2021

Periódico Quadrimestral da Pós-Graduação Stricto Sensu em Direito Processual da UERJ

Patrono: José Carlos Barbosa Moreira (in mem.). ISSN 1982-7636. pp. 1067-1124

www.redp.uerj.br

relações, se resolver essa segunda questão de fato, julga-se em decisão parcial de mérito as relações que forem possíveis, com a manutenção da litispendência em busca da instrução probatória do fato que não foi resolvido ainda, com a prolação ulterior da sentença.

Há uma bifurcação cognitiva entre os pedidos, porém também há a interligação entre os pedidos, que são autônomos na matéria, mas dependentes sobre a mesma questão de fato, o que importa no impacto em caso de provimento do recurso que impugnar a definição fática.

\section{ASPECTOS CONCLUSIVOS}

A processualidade brasileira trabalha, como uma busca pela simplicidade, para a construção procedimental de uma demanda simples, com uma relação jurídica a ser resolvida, diante de uma parte em cada polo.

Todavia, é possível, como analisado, uma complexidade objetiva do processo, com mais relações jurídicas a serem resolvidas na jurisdição, tanto em pluralidade de partes quanto em cumulação de pedidos.

Diante da complexidade objetiva do processo, o mérito do processo se divide em capítulos, com a divisão interna de uma sentença que enfrenta o mérito. No entanto, se há essa divisão, há a necessidade da unicidade da sentença? De uma só sentença sobre o pedido integral de jurisdição ou pode bipartir o processo? A resposta deve ser construída pela visão de que a unicidade é a regra e a busca da construção procedimental normal no ordenamento brasileiro, contudo as circunstâncias fático-jurídicas possibilitarão a cisão procedimental, dada a cisão cognitiva que o processo apresenta.

A possibilidade decisão cognitiva em um processo objetivamente complexo passa pela resolução de questões de fato e a abertura para que parcela do processo seja julgado antecipadamente e o restante do processo ainda necessite de produção de provas, com a postergação para um momento posterior.

indenizar. Se uma questão de fato for possível sobre um réu e o sobre a conduta do outro necessitar de uma questão de fato ser instruída, logo, será possível a decisão parcial de mérito sobre o primeiro réu a ser julgado. Nas intervenções de terceiros também são possíveis, como na denunciação da lide, a questão de fato sobre a lide principal ser possível de resolubilidade e gerando a procedência em decisão parcial, pode-se continuar o processo para a instrução entre o denunciado e o denunciado, se houver questão de fato a se discutir sobre o dever de indenizar do litisdenunciado. 
Quanto mais complexo objetivamente for um processo, a tendência é existir mais questões de fato a serem enfrentadas, o que importa em uma pluralidade de questões de fato. E o modo com que estas se relacionam com cada capítulo da demanda é importante para o estabelecimento da influência em cada matéria, em cada pedido.

A cisão cognitiva e o fracionamento decisório são inerentes ao próprio processo objetivamente complexo, mas dependem de uma pluralidade de questão de fatos a serem resolvidas, uma vez que somente constando uma questão de fato na demanda, com duas relações jurídicas, com ambas dependendo de tal resolubilidade, quando esta sobrevier, o processo estará pronto para a prolação da sentença.

Consequentemente, há a necessidade no processo objetivamente complexo que haja uma pluralidade de questões de fato, para, após a percepção cognitiva sobre estas e suas possíveis resolubilidades e impactos em cada capítulo, entender que há uma bifurcação cognitiva e, diante disso, torna-se possível o fracionamento decisório e a decisão parcial.

Em qualquer processo, a resolubilidade da questão de fato é antecedente às questões de direito, com a necessidade de uma cognição prévia num caminho anterior a ser seguido para conceder a aptidão à resolução da questão de direito e, posteriormente, a decisão como um todo.

Numa hipótese de um processo complexo objetivamente, cada capítulo terá uma relação própria com as questões de fato, seja uma relação com uma questão ou com várias questões. E, ainda, essa questão de fato pode ser impactante para diversos capítulos concomitantemente, sem necessariamente ser uma relação de modo fechado e estanque com um só capítulo.

Há, portanto, uma grande dinâmica complexa entre as relações jurídicas a serem solucionadas e a quantidade de questões de fato que lhe subsidiarão.

As questões de fato existentes num processo objetivamente complexo podem ser plurais ou somente uma, o que não ensejaria um fracionamento, mesmo com a complexidade do processo, como exposto. Para que os capítulos decisórios sejam fracionáveis necessita-se de duas possibilidades inter-relacionais com as questões de fato e os capítulos: (i) pluralidade de questões de fato e interligação específica de cada pedido com um fato; (ii) pluralidade de questões de fato, com uma destas com impacto em ambos os pedidos e uma outra questão de fato que impacta somente um dos pedidos. 
Mesmo diante de um processo complexo objetivamente, o que determinará a possibilidade de cisão será a relação da demanda e de seus capítulos decisórios autônomos com as questões de fato, seja da própria demanda, seja de situações específicas, como fatos atinentes a um pressuposto processual específico.

Para tanto, há de se separar a complexidade objetiva do processo e as questões de fato da relação entre cada capítulo, a sua complexidade entre admissibilidade e mérito e as questões de fato inerentes à admissibilidade.

\section{REFERÊNCIAS}

ALVIM, Arruda. Novo contencioso cível no CPC. São Paulo: Ed. RT, 2016.

ALVIM, Teresa Arruda. Distinção entre questão de fato e questão de direito para fins de cabimento de recurso especial. Revista de Processo. vol. 92. p. 52-70. São Paulo: Ed. RT, 1998.

AMBRIZZI, Tiago Ravazzi. Julgamento fracionado do mérito no processo civil brasileiro. São Paulo, SP, 2014. 231 p. Dissertação (Mestrado). Universidade de São Paulo. Programa de Pós-Graduação em Direito.

ARAÚJO, José Henrique Mouta. A resolução parcial de mérito e a coisa julgada progressiva: reflexos no sistema processual como forma de assegurar a brevidade da prestação jurisdicional. Belém, PA, 2004. 302 p. Tese (Doutorado). Universidade Federal do Pará. Programa de Pós-Graduação em Direito.

ARMELIN, Donaldo. Notas sobre sentença parcial e arbitragem. Revista de Arbitragem e Mediação. n. 18, v. 5, São Paulo: Ed. RT, jul/set/2008.

ASSIS, Araken de. Cumulação de ações. 4a . ed. São Paulo: Ed. RT, 2002. . Processo civil brasileiro: parte geral - fundamentos e distribuição de conflitos. Vol. I, São Paulo: Ed. RT, 2015.

BARBI, Celso Agrícola. Ação declaratória principal e incidental. 7a. ed. Rio de Janeiro: Forense, 1995.

BARBOSA, Bruno Valentim. Julgamentos parciais de mérito no processo civil individual brasileiro. São Paulo, SP, 2013. 161 p. Dissertação (Mestrado). Universidade de São Paulo. Programa de Pós-Graduação em Direito. 
BARBOSA MOREIRA, José Carlos. Questões prejudiciais e questões preliminares.

Direito processual civil (ensaios e pareceres). Rio de Janeiro: Borsoi, 1971.

. O novo processo civil brasileiro. $20^{\circ}$. ed. Rio de Janeiro: Forense, 2000.

- Sentença objetivamente complexa, trânsito em julgado e rescindibilidade.

Revista Dialética de Direito Processual. Vol. 45, São Paulo: Dialética, dez/2006.

CALMON DE PASSOS, José Joaquim. Comentários ao código de processo civil. Vol. III, $6^{\text {a }}$ ed. Rio de Janeiro: Forense, 1989.

CÂMARA, Alexandre Freitas. O novo processo civil brasileiro. $4^{\mathrm{a}}$ ed. São Paulo: Atlas, 2018.

CARVALHO, José Orlando Rocha de. Teoria dos pressupostos e dos requisitos processuais. Rio de Janeiro: Lumen Juris, 2005.

CUNHA, Leonardo José Carneiro da. O $\S 6^{\circ}$ do art. 273 do CPC: Tutela Antecipada Parcial ou Julgamento Antecipado Parcial da Lide? Revista Dialética de Direito Processual. n. 1, p. 109-126, São Paulo: Dialética, Abril/2003.

CUNHA, Leonardo Carneiro da; DIDIER JR., Fredie. Curso de direito processual civil. Vol. 3. 13 ${ }^{\mathrm{a}}$. ed. Salvador: JusPodivm, 2016.

DIAS, Jean Carlos. A reforma do CPC (LGL11973\5) e o fim da teoria da unidade da sentença - Lei 11.232/2005. Revista Dialética de Direito Processual. Vol. 40, p. 7984, São Paulo: Dialética, Jul/2006.

DIDIER JR., Fredie. Objeto da cognição judicial. Revista Dialética de Direito Processual. Vol. 6, p. 12-23, São Paulo: Dialética, set/2003. Inovações na antecipação dos efeitos da tutela e a resolução parcial do mérito. Revista de Processo. Vol. 110, Ano 28, p. 225-251, São Paulo: Ed. RT, abr/jun/2003. . Curso de direito processual civil: teoria geral do processo e processo de conhecimento. $17^{\mathrm{a}}$. ed. Salvador: Juspodivm, 2015. Comentários ao art. 485. In: CABRAL, Antônio do Passo; CRAMER, Ronaldo (Coord.). Comentários ao novo Código de Processo Civil. Rio de Janeiro: Forense, 2015.

DINAMARCO, Cândido Rangel. O conceito de mérito em processo civil. Revista de Processo. Vol. 34, Ano 9, p. 20-46, São Paulo: Ed. RT, Abril/Jun/1984. A reforma da reforma. $3^{\text {a }}$. ed. São Paulo: Malheiros, 2002. 
Instituições de direito processual civil. Vol. III. $3^{\text {a }}$. ed. São Paulo: Malheiros, 2003.

Capítulos de sentença. $3^{\mathrm{a}}$. ed. São Paulo: Malheiros, 2008.

. Litisconsórcio. 8a . ed. São Paulo: Malheiros, 2009.

DOTTI, Rogéria Faria. A tutela antecipada em relação à parte incontroversa da demanda. 2a. ed. São Paulo: Ed. RT, 2003.

FABRÍCIO, Adroaldo Furtado. Ensaios de direito processual. Rio de Janeiro: Forense, 2003.

FONSECA, João Francisco Naves da. Exame dos fatos nos recursos extraordinário e especial. São Paulo, SP, 2010. 192 p. Dissertação (Mestrado). Universidade de São Paulo. Programa de Pós-Graduação em Direito.

GRECO FILHO, Vicente. Direito processual civil brasileiro. Vol II. 16 ${ }^{\mathrm{a}}$. ed. São Paulo: Saraiva, 2003.

GRINOVER, Ada Pellegrini. O julgamento antecipado da lide: enfoque constitucional. Revista de Processo. Vol. 5, Ano 2, p. 101-114, São Paulo: Ed. RT, Jan/Mar/1977.

GOUVEIA FILHO, Roberto P. Campos. O art. 356, CPC, é base normativa suficiente para regular 0 fracionamento decisional? (final) https://emporiododireito.com.br/leitura/o-art-356-cpc-e-base-normativa-suficientepara-regular-o-fracionamento-decisional-final

LIMA, Alcides Mendonça de. As providências preliminares no código de processo civil brasileiro de 1973. Revista de Processo. Vol. 1, Ano 1, p. 26-42, São Paulo: Ed. RT, 1976.

LUCCA, Rodrigo Ramina de. Julgamentos antecipados parciais de mérito. Revista de Processo. Vol. 257, Ano 41, p. 125-150. São Paulo: RT, jul/2016.

MACÊDO, Lucas Buril. Coisa julgada sobre fato? análise comparativa com o collateral estoppel de sua possibilidade de lege lata ou de lege ferenda. Revista de Processo. vol. 260, p. 355 - 412, São Paulo: Ed. RT, Out / 2016.

MACHADO, Hugo de Brito. As questões de fato e a sentença de mérito. Revista Dialética de Direito Processual. Vol. 96, p. 65-71, São Paulo, mar/2011.

MALUF, Carlos Alberto Dabus. As presunções na teoria da prova. Revista de Processo. Vol. 24, Ano 6, p. 62-88, São Paulo: Ed. RT, Out/Dez/1981. 
MARINONI, Luiz Guilherme. Tutela Antecipatória, julgamento antecipado e execução imediata da sentença. $2^{\mathrm{a}}$. ed. São Paulo: Ed. RT, 1998. . Novas linhas do processo civil. 3• ed. São Paulo: Malheiros, 1999.

. Abuso de defesa e parte incontroversa da demanda. São Paulo: Ed. RT, 2007.

MARINONI, Luiz Guilherme; ARENHART, Sérgio Cruz; MITIDIERO, Daniel. Novo código de processo civil comentado. São Paulo: Ed. RT, 2015.

MEIRELES, Edilton. Julgamento antecipado parcial do mérito. Revista de Processo. Vol. 252, Ano 41, p. 133-146, São Paulo: Ed. RT, fev/2016.

NOGUEIRA, Gláucia Assalin. O julgamento parcial: possibilidade de cisão do julgamento de mérito relativamente à parte incontroversa da demanda. São Paulo, SP, 2009. 191 p. Dissertação (Mestrado). Universidade de São Paulo. Programa de Pós-Graduação em Direito.

ROCHA, José de Moura. Sobre os procedimentos especiais. Revista de Processo. Vol. 53, Ano 14, p. 22-30, São Paulo: Ed. RT, jan/mar/1989.

SCARPARO, Eduardo Kochenborger. Sentenças parciais? Considerações a partir de reforma do art. 162, $\S 1^{\circ}$, do CPC. Revista de Processo. n. 148, Ano 32, p. 153-168, São Paulo: Ed. RT, Jun/2007.

SICA, Heitor Vitor Mendonça. Algumas implicações do novo conceito de sentença no processo civil, de acordo com a lei $\mathrm{n}^{\mathrm{o}}$. 11.232/2005. In: Carlos Alberto Carmona. (Org.). Reflexões sobre a reforma do Código de Processo Civil. $1^{\mathrm{a}}$ ed. São Paulo: Atlas, 2007.

SICA, Heitor Vitor Mendonça. Comentário ao art. 1.015. In: STRECK, Lenio Luiz; NUNES, Dierle; CUNHA, Leonardo (orgs.). Comentários ao código de processo civil. $2^{\text {a }}$. ed. São Paulo: Saraiva, 2017.

SIQUEIRA, Thiago Ferreira. O julgamento antecipado parcial do mérito no Novo Código de Processo Civil brasileiro. Civil Procedure Review. Vol. 7, p. 165-208, 2016.

OLIVEIRA, Vallisney de Souza. Nulidade da sentença e o princípio da congruência. São Paulo: Saraiva, 2004. 
OLIVEIRA FILHO, Silas Dias de. Julgamento fracionado do mérito e implicações no sistema recursal. São Paulo, SP, 2013. 256 p. Dissertação (Mestrado). Universidade de São Paulo. Programa de Pós-Graduação em Direito.

TESHEINER, José Maria Rosa; THAMAY, Rennan Faria Kruger. Teoria Geral do Processo: em conformidade com o Novo CPC. Rio de Janeiro: Forense, 2015.

THAMAY, Rennan Faria Kruger. Manual de direito processual civil. São Paulo: Saraiva, 2018.

THEODORO JR., Humberto. Curso de direito processual civil. Vol. I, 59a ed. Rio de Janeiro: Forense, 2018.

WAMBIER, Luiz Rodrigues; TALAMINI, Eduardo. Curso avançado de processo civil. vol. 2, 5a . ed. São Paulo: Ed. RT, 2016.

YOSHIKAWA, Eduardo Henrique de Oliveira. A distinção entre prescrição e decadência no Direito brasileiro e a teoria da ação de direito material. Revista Dialética de Direito Processual. Vol. 109, p. 9-27, São Paulo: Dialética, 2012. 